\title{
La jurisprudencia de la Corte Interamericana de Derechos Humanos sobre el derecho a la propiedad, ¿concepción liberal o republicana?
}

The jurisprudence of the Inter-American Court of Human Rights on the right to property, liberal or Republican conception?

Sergio Fuenzalida Bascuñán ${ }^{1}$ Facultad de Derecho y Humanidades, Universidad Central de Chile, Chile sfuenzalidab@ucentral.cl

\begin{abstract}
Resumen: El trabajo revisa la jurisprudencia de la Corte Interamericana de Derechos Humanos en relación al artículo 21 de la Convención Americana, identificando el contenido y alcance a la protección conferida a la propiedad privada, en sus distintas modalidades y aspectos, con el objeto de reconocer elementos liberales o republicanos en los fallos, y la recepción de distintas formas de dominio. Las concepciones liberales o republicanas de la propiedad, que sirven para justificar en términos generales la inhibición o, por el contrario, la intervención del Estado en el uso y distribución de los bienes, están presentes en la jurisprudencia interamericana sin que aparezca una preferencia clara por ninguna de ellas.
\end{abstract}

1 Profesor de Derecho Constitucional y Derechos Humanos de la Facultad de Derecho y Humanidades de la Universidad Central de Chile 
Palabras clave: Propiedad privada, liberalismo, republicanismo, derechos humanos, jurisprudencia, Corte Interamericana de Derechos Humanos.

Summary: The work reviews the jurisprudence of the Inter-American Court of Human Rights in relation to Article 21 of the American Convention, identifying the content and scope to the protection conferred on private property, in its different modalities and aspects, in order to recognize liberal elements or republicans in sentences, and the reception of different forms of domain. The liberal or republican conceptions of the property, which serve to justify in general terms the inhibition or, on the contrary, the intervention of the State in the use and distribution of the goods, are present in the inter-American jurisprudence without a clear preference for none of them.

Keywords: Private property, liberalism, republicanism, human rights, jurisprudence, Inter-American Court of Human Rights.

\section{Introducción}

La jurisprudencia de la Corte Interamericana de Derechos Humanos en relación a la propiedad privada se puede dividir entre aquella que refiere a la propiedad indígena, que atribuye una alcance y contenido al artículo 21 de la Convención Americana característicamente singular, de la jurisprudencia que refiere a la propiedad no indígena, que aborda al derecho de propiedad de un modo que revisaremos aquí y que encuentra muchos puntos de convergencia con las categorías habituales que utilizan los tribunales nacionales.

En el presente texto revisaremos la jurisprudencia de la Corte Interamericana que refiere a propiedad privada de titulares no indígenas. En relación a la propiedad indígena y las decisiones de la Corte, ya existe un amplio desarrollo analítico sobre la materia².

El examen de la jurisprudencia interamericana sobre el dominio priva-

2 Para una revisión de dicha jurisprudencia, ver Corte IDH, Pueblos Indígenas y Tribales, Cuadernillo de Jurisprudencia de la Corte Interamericana de Derechos Humanos $N^{\circ} 11$. También Derechos de los pueblos indígenas y tribales sobre sus tierras ancestrales y recursos naturales. Normas y jurisprudencia del Sistema Interamericano de Derechos Humanos. 2010. 
do se hará a partir de dos concepciones diferentes sobre el origen de la propiedad: la concepción liberal y la concepción republicana. Para ello previamente realizaremos un esbozo de dos concepciones filosóficas principales que explican y desarrollan este punto. Luego intentaremos identificar los elementos de la jurisprudencia interamericana que pueden responder a una u otra concepción doctrinaria y si podemos afirmar por cuál de esas dos posiciones se inclina la Corte.

\section{Las concepciones liberales y republicanas sobre el origen de la propiedad: derecho pre-político o derecho de configuración social}

El derecho de propiedad desde las teorías que explican su origen pueden dividirse en dos vertientes principales: individual-liberal y social-republicana, lo que se vincula fuertemente con el fundamento de ese mismo derecho como derecho natural o político ${ }^{3}$. La cuestión sobre el origen de la propiedad tiene una amplia repercusión a propósito de la comprensión sobre su contenido y alcance.

La versión liberal del derecho de propiedad ha tenido como uno de sus principales exponentes a John Locke (1632- 1704), para quien su origen y justificación se encuentra en la labor del hombre. Dios ha dado el mundo a los hombres en común y les dio la razón para utilizar sus recursos en su beneficio. Como la naturaleza le fue entregada para su uso a los hombres, para el aprovechamiento de sus frutos, tiene que haber un medio de apropiación de las cosas que permitan su utilización o beneficio particular, y de esta manera la supervivencia y el desarrollo de cada individuo. Este modo de apropiación vendría dado por la capacidad de proyección del hombre en las cosas.

Cada hombre tiene para el autor inglés una "propiedad" en su propia "persona", a la cual sólo él tiene derecho. De la misma manera, como extensión natural, "la labor de su cuerpo y el "trabajo" de sus manos, podríamos decir que son suyos de su propiedad"4. De alguna manera se

3 MARTi, (2014), p. 176 y 177.

4 LOCKE, (2002), p. 25 
mezcla la labor del hombre con lo producido por su actividad 5 . Cualquier cosa natural que el hombre modifique con su trabajo, añadiéndole algo que es propio, se convierte en su propiedad y "excluye el derecho común de los otros hombres", al menos en la medida que sigan existiendo bienes comunales suficientes y de buena calidad para los demás ${ }^{6}$. Y, para que nazca este derecho, no es necesario ningún pacto expreso entre los miembros de la sociedad, no se requiere consentimiento alguno; nace por consiguiente antes de la constitución de la sociedad política. "Así, a partir de los dos postulados -que los hombres tienen derecho a conservar su vida, y que el trabajo de un hombre es propiedad suya-justifica Locke la apropiación individual del producto de la tierra originalmente entregado a la humanidad en común"?.

El pacto social, y en consecuencia la constitución de la sociedad política, se explica y se justifica precisamente "para la preservación mutua de sus vidas, libertades y posesiones, es decir, de todo aquello a que doy el nombre general de "propiedad"'8. Por lo mismo, los derechos naturales son anteriores a la sociedad política, y protegen a las posesiones individuales adquiridas. Ello, siguiendo a Macpherson, bajo el entendido que los bienes al momento del contrato social ya se encuentran desigualmente distribuidas debido a la introducción del dinero (surgida en la etapa previa y mediando para ello un acuerdo tácito), elemento que permite sortear las restricciones iniciales a la acumulación y hacen inevitable e incluso deseable la provisión ilimitada de capital ${ }^{9}$.

Por su lado, la versión social-republicana del derecho de propiedad enfrenta la cuestión desde un punto de vista distinto. Para esa filosofía la propiedad sólo nace con la constitución de la comunidad política y por lo mismo es un derecho de configuración legal. A diferencia de la concepción lockeana, el contenido y alcance de la propiedad, como de los demás derechos, va a estar determinado por el orden social.

5 WALDRON, (1988), p. 184.

6 LOCKE, (2002), p. 2.

7 MACPHERSON, (2005), p. 199.

8 LOCKE, (2002) p. 89.

9 MACPHERSON, (2005), p. 211. 
Para Rosseau el pacto social con el cual se constituye un pueblo y se supera el estado de naturaleza implica "la enajenación total de cada asociado con todos sus derechos a toda la comunidad"10. Se trata de un contrato donde "cada uno de nosotros pone en común su persona y todo su poder bajo la suprema dirección de la voluntad general; y nosotros recibimos corporativamente cada miembro como parte indivisible del todo"11. Se trata de un acto de mutua y total entrega, para a partir de ahí definir los derechos y deberes de los integrantes, con el consiguiente compromiso con cada uno de nosotros como miembro indispensable e inseparable del colectivo.

El soberano lo constituye el pueblo como un todo reunido, pero no para ejercer ese poder soberano despóticamente. Eso sería un contrasentido. El pueblo es soberano y súbdito a la vez, por lo que resultaría inconcebible que siendo a la vez juez y parte disponga algo en su perjuicio. A condición de que las decisiones colectivas (convenciones) sean adoptados por todos, tengan un alcance general y por lo mismo sean aplicables a todos por igual --bajo la premisa de que "todo acto auténtico de la voluntad general obliga o favorece igualmente a todos los ciudadanos"12 -- la soberanía no sobrepasará sus propios límites. Así, todo hombre podrá "disponer plenamente de lo que sus bienes y de su libertad le han dejado esas convenciones"13, las que, a su vez, sólo pueden disponer de aquello que es útil a la comunidad y que refiere a aspectos de mutuo beneficio ${ }^{14}$.

Por lo mismo, a partir del contrato social se adquiere la libertad civil y la propiedad sobre los bienes. Antes, sólo existe la posesión como efecto del derecho del primer ocupante, pero aquello no refiere a un derecho

10 Rosseau, (2003), p. 39

11 lbídem

12 Ibídem, p. 56

13 Ibídem, p. 57

14 Rosseau había escrito 8 años antes del Contrato Social el Discurso sobre la Economía política en donde aseveró que "el fundamento del pacto social es la propiedad y su primera condición la de que todos sean mantenidos en el pacífico disfrute de sus pertenecías". Esta declaración, que lo acercaría a posiciones liberales, no le impide al autor hacer en el mismo texto una fuerte defensa al rol del gobierno para cumplir uno de sus tareas más importantes, cual es, "prevenir la extrema desigualdad en las fortunas", y justificar la imposición de distintos impuestos y cargas para la satisfacción de objetivos colectivos. Rosseau, (2001), p. 28 y 44. 
positivo a la propiedad. La propiedad en rigor nace a partir del pacto social donde se establece principalmente el respeto "de lo que no es de uno", los límites constituidos por lo ajeno ${ }^{15}$. También, aspecto clave: "el contrato social es el que decide qué bienes van a pasar a ser propiedad privada y cuáles permanecerán siendo bienes comunes"16.

La propiedad, para esta concepción social o política, necesariamente se constituiría como relación intersubjetiva y no una mera titularidad sobre las cosas. La propiedad no refiere a un control directo sobre la cosa, "sino más bien a mi relación contigo, y con el resto del mundo"17, otorgando el poder al tenedor del bien a excluir a los demás de su uso y goce. Lo cual supone necesariamente un orden jurídico o, en palabras de Kant, un "estado civil", ya que otro modo no se configuraría la obligación universal ${ }^{18}$.

En una aproximación consistente con lo dicho anteriormente, Kelsen es posiblemente el autor que de manera más clara ha planteado la subordinación de la propiedad, y de los derechos subjetivos en general, al orden jurídico objetivo estatal, cualquiera sea su naturaleza. Para al autor austriaco, la propiedad privada concebida como derecho de naturaleza subjetiva y como un derecho real, constituye un claro dispositivo ideológico. Los derechos subjetivos (entre los cuales está la propiedad como pieza clave) son una técnica de un modelo específico de orden social: el capitalismo. Es el derecho objetivo el que crea los derechos subjetivos (como podría no hacerlo bajo otro modelo económico) y no es más que un aspecto de éste ${ }^{19}$.

También la diferenciación entre derecho objetivo y subjetivo, como es-

15 Rosseau (2003), p. 45

16 MARTi (2014), p. 189

17 ROSE (2001), p. 198.

18 Ruiz-TAgle (2014), p. 111 y 112. . Nos dice Peña al respecto: "Kant sugiere que una cosa es la posesión física de la cosa que provee un título empírico, que alude a la posesión fenoménica. A ella se debe seguir un intelectual por la que declaro algo como mío. Pero un título racional solo puede venir de la voluntad de todos. Antes de ella hay una adquisición meramente provisional, la adquisición perentoria exige un estado civil". PEÑA (2018), p. 53.

19 Incluso el hombre y el sujeto de derecho es "sustituido por la unidad «unidad de las normas jurídicas que obligan y autorizan a un mismo hombre», esto es "un complejo de normas»". LóPEZ y LóPEZ (1996), p. 425 
feras separadas, cumple una función meramente estratégica: se trata "de mantener la idea de que el derecho subjetivo, es decir, la propiedad privada, es una categoría trascendente al derecho objetivo, una institución que le impone límites infranqueables" 20 . Pero la verdad es lo otra: es el derecho objetivo, la norma positiva, quien decide y configura los derechos de las personas.

Lo mismo puede concluirse de la concepción de la propiedad como derecho real. Lo que esta categorización esconde, según Kelsen, es la realidad manifiesta de que "el dominio jurídico de una persona sobre una cosa consiste exclusivamente en una relación entre un sujeto y otros sujetos, o más exactamente, en una relación entre la conducta de un individuo y la de otro u otros individuos, a saber, en la posibilidad jurídica para el propietario de impedir a todos los otros sujetos gozar de la cosa y en el deber de estos de no coartar la facultad del propietario de disponer de ella"21. Se trata en consecuencia no de una relación entre un individuo y la cosa, que el derecho descubre y protege; constituye, por el contrario, una relación entre personas y configurada por el derecho objetivo que establece el poder del dueño sobre su bien, y como "un aspecto secundario del deber de los otros sujetos de derecho"22.

Este debate, como se comprende, no se circunscribe a un análisis exclusivamente jurídico. La propiedad y las distintas concepciones sobre ella, desde la filosofía política, constituye un aspecto central en el ordenamiento social. La dicotomía estaría dada por la forma de concebir el dominio según el modo, podemos llamar, ateniense o el romano. Para los primeros "la propiedad se constituye por la mediación del reconocimiento social; mientras que, en el romano, esta se constituye abstractamente como una relación inmediata entre una persona y una cosa"23. Por lo mismo, bajo el modelo ateniense es la sociedad, a través de las leyes, quien configura el contenido y alcance de la propiedad, en cambio, bajo

20 KeLSEN (2013), pp. 96-97.

21 KeLSEN (2013), p. 98.

22 Ibídem

23 RUIZ-TAGLE (2014a), p. 40 
la concepción romana-moderna, el derecho de propiedad es anterior a la comunidad política, y esta última se constituye para proteger la vida y propiedad de quienes participan en el pacto social. En el primer paradigma la propiedad está atravesada por los requerimientos de la comunidad política, en el segundo la comunidad política se debe al propietario.

A su vez, la perspectiva ateniense se vincula con la concepción republicana de la propiedad. Y ello no sólo por razones de justicia distributiva, sino porque es posible sostener que la estabilidad del sistema político democrático está condicionada por la participación en los bienes. Como lo sostuviera Harrington, la estabilidad y la legitimidad del gobierno depende de un adecuado balance de la propiedad ${ }^{24}$. Solo es posible pensar en un sistema social y político estable, y sin altas dosis de violencia, si existen niveles adecuados de distribución de los bienes. Asimismo, la adecuada distribución de la propiedad para la concepción republicana puede servir de antídoto contra la corrupción del sistema político (Machiavelo $)^{25}$, un requisito para una virtud cívica libre (Harrington) ${ }^{26}$, o como un instrumento para la no-dominación (Pettit) ${ }^{27}$.

Por ello, en la manera de concebir el origen de la propiedad, se juega algo tan importante como es la posibilidad abierta para el poder político de ordenar el dominio en razón de los intereses colectivos o, por el contrario, restringir esa posibilidad. Como, asimismo, habilitar al Estado para disponer de políticas de redistribución de la propiedad más o menos intensas ${ }^{28}$. Lo central, en consecuencia, es la concepción de la propiedad no como un fin en sí mismo, que haya que ocasionalmente limitar en aras de un bien mayor. Más bien se trata de concebir la propiedad como un instrumento para la consecución del bien común, el cual se alcanzaría superando dominación de unos por otros, ya sea horizontal (la que ejercen unos ciudadanos sobre otros) o vertical (la que ejerce el poder

24 Ruiz-TAgle (2014b), pp. 38-39

25 Pocock (2016), p. 297.

26 Ibídem, p. 472 y 476. Ruiz-TAgle, P. (2014a), p. 60,

27 Pettit (199), p. 180. Marti (2014), p. 213

28 Ruiz-TAgLe (2014b), p. 42. 
público más allá del "control último de la ciudadanía) ${ }^{29}$.

La discusión, por tanto, sobre el origen de la propiedad, ya sea como derecho real subjetivo pre-estatal o como derecho de configuración social, tiene un efecto inmediato en la posibilidad de regular o condicionar con menor o mayor intensidad la relación humana sobre las cosas. Asimismo, en la definición de las esferas de la propiedad privada y pública.

\section{La jurisprudencia de la Corte Interamericana de Derechos Humanos en materia de propiedad (no indígena)}

La propiedad está incorporada como un derecho humano en declaraciones internacionales, determinados tratados internacionales y dentro del catálogo en las convenciones regionales de derechos humanos: interamericano, europeo y africano ${ }^{30}$. No está reconocida en los dos principales tratados universales en la materia: los Pactos Internacionales de Derechos Humanos del año 1966. Aquello se explica por el contexto histórico de guerra fría donde nacieron estos últimos acuerdos, donde era muy improbable alcanzar un consenso sobre un tema que dividía tan profundamente a los mundos socialista y capitalista ${ }^{31}$. De hecho, este derecho generó una intensa discusión en el trabajo preparatorio de la Convención Americana, incluida una propuesta para eliminarlo (fundado en diferentes razones: por no constituir un derecho fundamental, por ser propiamente un DESC, por ser un asunto que debe estar entregado a la soberanía estatal; por constituir un obstáculo a los procesos de reforma

29 MARTi (2014), pp. 203 y 204.

30 A nivel internacional, este derecho se encuentra reconocido en los siguientes instrumentos: (1) La Declaración Universal de Derechos Humanos: señalando específicamente en el artículo $17^{\circ}$ el derecho a la propiedad individual y la propiedad colectiva; (2) La Convención Internacional sobre la protección de los derechos de todos los trabajadores migrantes y sus familias; estipulado en el artículo $15^{\circ}$ de la misma norma. A nivel de normativa regional está consagrado en: (1) La Declaración Americana de los Deberes y Derechos del Hombre: en su artículo XIII; (2) La Convención Americana sobre Derechos Humanos: en su artículo $21^{\circ}$; (3) El Protocolo Adicional 1 al Convenio Europeo de Derechos Humanos; (4) La Carta Africana de Derechos Humanos y de los Pueblos: en su artículo $14^{\circ}$. A ello hay que agregar la (5) Convención sobre la eliminación de todas las formas de discriminación contra la mujer que en su artículo 16 también reconoce dicho derecho, y la (6) Convención interamericana sobre la protección de los derechos humanos de las personas mayores, que consagra explícitamente el derecho en su artículo 23.

31 LÓPEZ (2015), p. 533. 
agraria, etc.), pero finalmente fue incluido dentro del listado de derechos convencionales ${ }^{32}$.

La consagración convencional del derecho a la propiedad privada que funda la jurisprudencia de la Corte Americana de Derechos Humanos está en el siguiente artículo:

Artículo 21. Derecho a la Propiedad Privada

1. Toda persona tiene derecho al uso y goce de sus bienes. La ley puede subordinar tal uso y goce al interés social.

2. Ninguna persona puede ser privada de sus bienes, excepto mediante el pago de indemnización justa, por razones de utilidad pública o de interés social y en los casos y según las formas establecidas por la ley.

3. Tanto la usura como cualquier otra forma de explotación del hombre por el hombre, deben ser prohibidas por la ley.

El Tribunal ha dictado varias sentencias sobre el derecho de propiedad (no indígena) en diferentes aspectos: a) la definición de propiedad y el contenido de este derecho; b) sobre el límite de la propiedad y la posibilidad de expropiación de los bienes; c) sobre las formalidades y los requisitos en torno a la posibilidad de ordenar una medida cautelar real; y d) la propiedad y grupos o personas vulnerables.

\subsection{Definición de propiedad, aspectos materiales e inmateriales. Tipos de propiedad}

La Corte ha establecido un concepto amplio de propiedad en su jurisprudencia. Apoyada en el texto convencional que reconoce a toda persona el derecho de uso y goce de sus bienes, entiende que "[l]os 'bienes' pueden ser definidos como aquellas cosas materiales apropiables, así como todo derecho que pueda formar parte del patrimonio de una persona; dicho concepto comprende todos los muebles e inmuebles, los elementos corporales e incorporales y cualquier otro objeto inmaterial susceptible de valor"33. También ha señalado "que la propiedad es un

32 OEA (1969). Ver especialmente, Acta De La Undécima Sesión de la Comisión, de 17 noviembre 1969.

33 Corte IDH Caso Ivcher Bronstein Vs. Perú (2001). Fondo, Reparaciones y Costas. Sentencia 
concepto amplio que abarca, entre otros, el uso y goce de los bienes, definidos como cosas materiales apropiables, así como todo derecho que pueda formar parte del patrimonio de una persona"34.

Este concepto incluye los derechos sobre obras intelectuales, derechos sobre acciones en una sociedad anónima y los llamados derechos adquiridos.

\subsubsection{Propiedad sobre obras intelectuales}

Respecto de los primeros, los derechos intelectuales, la Corte ha dispuesto que "dentro del concepto amplio de "bienes" cuyo uso y goce están protegidos por la Convención, también se encuentran incluidas las obras producto de la creación intelectual de una persona, quien, por el hecho de haber realizado esa creación adquiere sobre ésta derechos de autor conexos con el uso y goce de la misma"35. Y agrega que "[l] a protección del uso y goce de la obra confiere al autor derechos que abarcan aspectos materiales e inmateriales. El aspecto material de estos derechos de autor abarca, entre otros, la publicación, explotación, cesión o enajenación de la obra y, por su parte, el aspecto inmaterial de los mismos se relaciona con la salvaguarda de la autoría de la obra y la protección de su integridad. El aspecto inmaterial es el vínculo entre el creador y la obra creada, el cual se prolonga a través del tiempo. Tanto el ejercicio del aspecto material como del aspecto inmaterial de los derechos de autor son susceptibles de valor y se incorporan al patrimonio de una persona"36.

\subsubsection{Propiedad sobre acciones}

La Corte ha hecho un amplio reconocimiento de estos bienes. A propósito de esto, ha distinguido entre la titularidad individual del título o valor

de 6 de febrero de 2001, párr. 122. Cfr.

34 Corte IDH Caso Perozo y otros Vs. Venezuela. Excepciones Preliminares, Fondo, Reparaciones y Costas. Sentencia de 28 de enero de 2009, párr. 399

35 Corte IDH. Caso Palamara Iribarne Vs. Chile. Fondo, Reparaciones y Costas. Sentencia de 22 de noviembre de 2005, párr. 102

36 Ibídem, párr. 103 
financiero que representa una parte alícuota del capital social de una sociedad anónima, del dominio de la compañía sobre su patrimonio social, rechazando una protección convencional sobre derechos pertenecientes a personas jurídicas.

En relación al titular de la protección de los derechos convencionales, el Pacto de San José establece que los Estados Partes "se comprometen a respetar los derechos y libertades reconocidos en ella y a garantizar su libre y pleno ejercicio a toda persona que esté sujeta a su jurisdicción (...)", pero aclara que para "los efectos de esta Convención, persona es todo ser humano", es decir, no incluye en principio a las personas jurídicas como titulares de los derechos convencionales. Esto se diferencia, por ejemplo, del sistema europeo de protección de los derechos humanos, por cuanto el Convenio Europeo no contiene una definición especifica del término persona, su jurisdicción está abierta a demandas por organizaciones no gubernamental o grupo de particulares, y, en relación a la propiedad privada, los términos del Protocolo Adicional al Convenio para la Protección de los Derechos Humanos y de las Libertades Fundamentales que consagran ese derecho, lo hace en los siguientes términos: "[t]oda persona física o moral tiene derecho al respeto de sus bienes" (la cursiva es nuestra) $)^{37}$.

La Corte Interamericana específicamente se ha pronunciado sobre este punto, estableciendo que "las personas jurídicas no son titulares de derechos convencionales, por lo que no pueden ser consideradas como presuntas víctimas en el marco de los procesos contenciosos ante el sistema interamericano"38.

Ahora bien, aquello no ha impedido considerar a los accionistas propiamente tales como dueños de sus activos financieros y como titulares

37 Corte IDH. Titularidad de derechos de las personas jurídicas en el Sistema Interamericano de Derechos Humanos (Interpretación y alcance del artículo 1.2, en relación con los artículos 1.1, 8, 11.2, 13, 16, 21, 24, 25, 29, 30, 44, 46, y 62.3 de la Convención Americana sobre Derechos Humanos, así como del artículo 8.1 A y B del Protocolo de San Salvador). Opinión Consultiva OC22/16 de 26 de febrero de 2016. Serie A No. 22, párrafo, 51 a 53.

38 Ibídem, párrafo, 70. Ello con excepción de derechos que pueden ser invocados por los pueblos indígenas, como titulares de algunos los derechos convencionales, y de determinados derechos que pueden ser esgrimidos por parte de los sindicatos. Ibídem, párr. 71 a 105 
de derechos de específicos en dicha calidad ${ }^{39}$. Desde el momento de la adquisición de una parte en el capital accionario de una empresa, esa porción es susceptible de valoración y forma parte del patrimonio del titular y, como tal, constituye un bien sobre el cual se tiene un derecho de uso y goce g. $^{40}$

La Corte, así, ha distinguido los derechos de los accionistas de una empresa de los derechos de la propia compañía, señalando que las leyes nacionales otorgan a los accionistas ciertos derechos directos, como recibir los dividendos acordados, asistir y votar en juntas generales y recibir parte de los activos de la empresa en el momento de su liquidación, entre otros. Pero, por lo mismo, para determinar si ha existido una vulneración al derecho de propiedad de los socios es necesario que se encuentre probada claramente la afectación que sobre sus derechos ha recaído ${ }^{41}$, es decir, "debe ser demostrado cómo el daño o afectación de los bienes de propiedad de la persona jurídica podrían llegar a implicar, a su vez, una afectación a los derechos de los accionistas o socios"42.

Un ejemplo claro de aquello es el caso Caso Granier y otros (Radio Caracas Televisión) Vs. Venezuela, donde las presuntas víctimas alegaron una violación del derecho de propiedad. En ese caso la Corte rechazó acoger el reclamo de una violación a la propiedad privada, por cuanto entendió que no era competente "para analizar las presuntas violaciones a la Convención que se hayan ocurrido en contra de personas jurídicas" 43 . Para la Corte, "los derechos de los accionistas de una empresa son diferentes de los derechos de la persona jurídica, por lo que para fines de desestimar la personalidad jurídica de la sociedad anónima y atribuir a los socios legitimidad para reclamar los daños generados a través de actos dirigidos a la empresa, [era] necesario contar con el material

39 Corte IDH. Caso Perozo y otros Vs. Venezuela, supra, párr. 70.

40 Corte IDH. Caso Ivcher Bronstein Vs. Perú. Fondo, Reparaciones y Costas. Sentencia de 6 de febrero de 2001, párr. 123

41 Corte IDH. Caso Granier y otros (Radio Caracas Televisión) Vs. Venezuela. Excepciones Preliminares, Fondo, Reparaciones y Costas, párr. 337 y 338

42 Corte IDH. Titularidad de derechos de las personas jurídicas ... párr. 114.

43 Corte IDH. Caso Granier y otros (Radio Caracas Televisión) Vs. Venezuela, supra, párr. 348. 
probatorio suficiente para demostrar dicha relación"44.

Pero, en la especie el Tribunal no fue persuadido de que existiera una "confusión de patrimonios" entre la persona jurídica y sus accionistas. Se trataba más bien de una empresa con una estructura accionaria "compleja": las presuntas víctimas eran accionistas de personas jurídicas o patrimonios autónomos separados, que a su vez eran accionistas o propietarios de una cadena que tenía en el intermedio entre una o hasta cinco otras personas jurídicas hasta llegar a la empresa periodística, por lo que no era posible tener por acreditado el perjuicio directo a los reclamantes ${ }^{45}$.

Distinto fue la decisión en el caso Chaparro Vs. Ecuador, donde la relación de propiedad entre la víctima y las acciones eran indudables. En esa ocasión la víctima tenía el $50 \%$ de las acciones de la empresa y era gerente de la misma, lo que hacía "evidente que esta participación en el capital accionarial era susceptible de valoración y formaba parte del patrimonio de su titular desde el momento de su adquisición. Como tal, esa participación constituía un bien sobre el cual el señor Chaparro tenía derecho de uso y goce"46.

Por su parte, la propiedad sobre acciones de una sociedad presenta otra particularidad en la jurisprudencia de la Corte Interamericana. Ello por cuanto, siguiendo la jurisprudencia de la Corte Internacional de Justicia, identifica el dominio sobre el activo financiero con los derechos directos que otorgan las leyes internas a esa titularidad, "como los de recibir los dividendos acordados, asistir y votar en las juntas generales y recibir parte de los activos de la compañía en el momento de su liquidación, entre otros". Como se verá más adelante, cuando nos refiramos al caso Ivcher Bronstein Vs. Perú, la Corte Interamericana estimó que la obstrucción al uso y goce de los derechos de decisión y administración asociados a la propiedad accionaria, en las condiciones del caso, implicó una

44 Ibídem, párr. 351 .

45 Ibídem, párr. 355.

46 Corte IDH. Caso Chaparro Álvarez y Lapo Íñiguez Vs. Ecuador. Excepciones Preliminares, Fondo, Reparaciones y Costas. Sentencia de 21 de noviembre de 2007, párr. 182 
privación de los bienes de la víctima, en contravención a lo establecido en el artículo 21.2 de la Convención.

Se equiparó de este modo las facultades propias del bien, con la titularidad del mismo, en circunstancias que hay autores que separa ambas cuestiones. Para un sector de la doctrina, por un lado está la propiedad sobre el bien incorporal, cuyo único contenido estaría dado por la facultad de disposición, y por otro, las facultades propias del bien en sí (creación puramente jurídica), que en el caso de las acciones estaría dada por los derechos de decisión y administración corporativos ya indicados ${ }^{47}$.

\subsubsection{Propiedad y "derechos adquiridos"}

La Corte se ha referido a los llamados "derechos adquiridos" en relación al monto de prestaciones sociales. En el Caso "Cinco Pensionistas" Vs. Perú, el Tribunal declaró la violación del derecho de propiedad sobre los derechos de los peticionarios sobre sus pensiones de cesantía.

El caso refería a la supuesta responsabilidad internacional originada por la modificación en el régimen de pensiones que las víctimas venían disfrutando conforme a la legislación peruana hasta 1992. Los beneficiarios adscritos a ese ese régimen legal tenían derecho a una pensión de cesantía que se ajustaba cada vez que se producía un incremento en la escala en las remuneraciones de los trabajadores y funcionarios activos. En abril de 1992 se había suspendido el pago de la pensión de una de las víctimas y reducido el monto de la pensión de los demás peticionarios en aproximadamente un $78 \%$, sin previo aviso ni explicación alguna. Luego se había dictado una ley que modificó la fórmula de cálculo para ajustarla a esa rebaja ${ }^{48}$. Cada uno de los pensionistas había interpuesto diversas acciones judiciales y obtenido sentencias favorables, pero ninguna de ellas había sido ejecutada por el órgano estatal encargado de pagar las respectivas pensiones.

La Corte observó que en el caso no existía controversia sobre si las

47 Fuentes (2018) pp. 263 a 267.

48 Corte IDH. Caso "Cinco Pensionistas" Vs. Perú. Fondo, Reparaciones y Costas. Sentencia de 28 de febrero de 2003, párr. 91 a) 
presuntas víctimas tienen derecho a pensión o no. Todas ellas habían obtenido el derecho a la pensión de cesantía bajo el régimen legal. La controversia radicaba en "si los parámetros utilizados por el Estado, para reducir o recalcular los montos de las pensiones de las presuntas víctimas a partir de 1992, configuran una violación del derecho a la propiedad de éstas" 49 . Por ello se debía analizar: "a) si el derecho a la pensión puede considerarse un derecho adquirido y qué significa esto; y b) qué parámetros deben tenerse en cuenta para cuantificar el derecho a la pensión, y si se pueden poner límites a éste" 50 .

En cuanto a la controversia a si el derecho a la pensión era o no un derecho adquirido, la Corte se remitió a lo resuelto por la Constitución Política del Perú y por el Tribunal Constitucional peruano, que habían calificado dichas prestaciones como derechos adquiridos ${ }^{51}$. En base a esto - más lo señalado en el artículo 29.b) de la Convención Americana, en el sentido de que ninguna disposición del tratado puede ser interpretado para limitar el goce y ejercicio de cualquier derecho o libertad reconocido de acuerdo a las leyes de los Estados partes ${ }^{52}$-- la Corte concluía al respecto que, "[e]n este orden de ideas, el artículo 21 de la Convención protege el derecho de los cinco pensionistas a recibir una pensión de cesantía nivelada de acuerdo al Decreto-Ley $N^{\circ} 20530$, en el sentido de que se trata de un derecho adquirido, de conformidad con lo dispuesto en la normativa constitucional peruana, o sea, de un derecho que se ha incorporado al patrimonio de las personas" 53 . En otras palabras, desde el momento que los beneficiarios se habían acogido al régimen de cesantía previsto en la legislación aplicable "los pensionistas adquirieron un derecho de propiedad sobre los efectos patrimoniales del derecho a la pensión", de conformidad a la ley vigente, "y en los términos del artículo 21 de la Convención Americana" ${ }^{4}$.

49 Corte IDH. Caso "Cinco Pensionistas" Vs. Perú, párr. 94

50 Ibídem, párr. 95.

51 lbídem, párr. 96.

52 Ibídem, párr. 101

53 Ibídem, párr. 102

54 Ibídem, párr. 103. 
Aclarado esto, la Corte se pronunció sobre los parámetros a tener en cuenta para cuantificar el derecho a la pensión, y los límites de este derecho. Sobre la cuantificación de la prestación, la duda radicaba sobre el tipo de régimen a que estaban afiliados los pensionistas, es decir, si se sujetaban al régimen privado o público al momento de nivelar sus prestaciones, siendo notoriamente más beneficioso la que correspondía al régimen privado. Sobre esto, la Corte también se remitió a los resuelto localmente. Observó que las mismas autoridades habían interpretado que las pensiones debían nivelarse según el régimen más favorable, reconociéndoles dicho derecho mediante sucesivos actos administrativos. $\mathrm{Y}$, más importante aún que ello, "los tribunales internos ordenaron seguirles pagando las mesadas pensionales en los términos en que se venía haciendo". Lo que "configuró, en beneficio de los pensionistas, un derecho amparado por las sentencias de garantía, que, al ser desconocido por el Estado, los afectó patrimonialmente, violando el artículo 21 de la Convención" 55 , agregó la Corte.

Ahora bien, aun cuando el derecho a la pensión configuraba un derecho adquirido para la Corte, de conformidad con el artículo 21 de la Convención, esto no impedía poner limitaciones a ese derecho, disminuyendo concretamente las prestaciones, por razones de utilidad pública o interés social, y sujetándose a los parámetros establecidos en la Convención. Es decir, "[e]n el caso de los efectos patrimoniales de las pensiones (monto de las pensiones), los Estados pueden reducirlos únicamente por la vía legal adecuada y por los motivos ya indicados". Aunque para ello, asimismo, había de tenerse en consideración el artículo 5 del Protocolo Adicional a la Convención Americana en materia de Derechos Económicos, Sociales y Culturales.

De este modo, la Corte no excluyó la posibilidad de cambiar los montos de las pensiones. Pero si el Estado peruano quería hacerlo, dándole una interpretación diferente a la legislación vigente, asimilando las pensiones de las víctimas a los ingresos percibidos por el sector público, "debió: a) realizar un procedimiento administrativo con pleno respeto a las garan-

55 Ibídem, párr. 115 
tías adecuadas, y, b) respetar, en todo caso, por sobre las decisiones de la administración, las determinaciones que adoptaron los tribunales de justicia"56. Cuestión que no se había hecho y, por ello, "al haber cambiado arbitrariamente el monto de las pensiones que venían percibiendo las presuntas víctimas y al no haber dado cumplimiento a las sentencias judiciales emitidas con ocasión de las acciones de garantía interpuestas por éstas (...), [el Estado] violó el derecho a la propiedad consagrado en el artículo 21 de la Convención"57.

llustrativo también sobre el alcance de los derechos adquiridos y las modificaciones legales es el Caso Abrill Alosilla y otros Vs. Perú donde le tocó al Tribunal analizar específicamente la aplicación retroactiva de normas que eliminaban el sistema de escala salarial que anteriormente regía a trabajadores públicos y que produjo la reducción de sus pensiones ya devengadas ${ }^{58}$. En este caso, la Corte dijo que ella "ha protegido, a través del artículo 21 convencional, los derechos adquiridos, entendidos como derechos que se han incorporado al patrimonio de las personas", resaltando que estos conforman uno de los fundamentos del "principio de la irretroactividad de la ley, es decir, que la nueva ley no tiene la virtud de regular o afectar las situaciones jurídicas del pasado que han quedado debidamente consolidadas, y que resultan intangibles e incólumes frente a aquélla, cuando ante una determinada situación de hecho se han operado o realizado plenamente los efectos jurídicos de las normas en ese momento vigentes" 59 .

Con todo, es importante resaltar que ni la Corte, como tampoco la Comisión ni los representantes de las víctimas, cuestionaron la validez de la derogación del sistema de "ratios salariales" que operaban en la empresa pública peruana SEDAPAL ${ }^{60}$, sino "la aplicación retroactiva de

56 Ibídem, párr. 117

57 Ibídem, párr. 123

58 Corte IDH. Caso Abrill Alosilla y otros Vs. Perú. Fondo, Reparaciones y Costas. Sentencia de 4 de marzo de 2011.

59 Ibídem, párr. 82. La cita pertenece a la sentencia C-147/97 de la Corte Constitucional de Colombia de 19 de marzo de 1997.

60 Ibídem, párr. 53 
la norma que implicó descuentos y omisiones de incrementos que les correspondían", los cuales "tuvieron efectos negativos sobre derechos adquiridos de los trabajadores en relación con la remuneración que había ingresado a su patrimonio" 61 . El problema radicaba en que mediante tres decretos diferentes se habían ampliado los supuestos en los que procedía la supresión de los sistemas de reajuste de salarios, pero todos ellos se remitían en su aplicación en el tiempo a la fecha de vigencia del primero, retrotrayendo de ese modo su vigencia ${ }^{62}$.

La Corte aclara con esto el alcance de los llamados derechos adquiridos. En la especie "no se trata de un derecho adquirido respecto a la aplicación del sistema de ratios salariales", sino que refiere "a los montos que ya habían ingresado al patrimonio de los trabajadores, así como a los incrementos al salario que se hubieran establecido bajo el sistema de ratios hasta antes de su derogación". El derecho adquirido, en consecuencia "se vio afectado por la aplicación retroactiva del referido Decreto Ley" lo que implicó para las víctimas dos cosas. Por una parte, ser objeto de un descuento porcentual de las remuneraciones mensuales que estaban recibiendo, como una forma (ilícita) de restituir lo entregado en exceso, y, por otra parte, la no aplicación de los incrementos que correspondían legalmente antes de la que ley modificatoria entrara en vigencia. De esta manera las víctimas no pudieron "gozar integralmente de su derecho a la propiedad sobre sus remuneraciones" 63 .

Como veremos más adelante, la decisión de la Corte es importante por cuanto no parece asignarles a los derechos adquiridos la virtud de hacer intangibles los derechos establecidos por ley a las personas en un momento dado. Aun cuando vincula los derechos adquirido a la proscripción de la retroactividad de la ley, va a aplicar una retroactividad "en grado medio", es decir, va a entender que la nueva ley puede aplicarse a la situación jurídica que tuvo su origen durante la vigencia de una ley ya derogada, pero ella sólo va a poder regular las consecuencias que hayan

61 Ibídem, párr. 81.

62 Corte IDH. Caso Abrill Alosilla y otros Vs. Perú, párr. 61

63 Ibídem, párr. 84. 
de ejecutarse a partir del momento de su entrada en vigor, sin afectar los efectos pasados ${ }^{64}$, algo muy similar a "la teoría de los hechos cumplidos" que actualmente rige en el Perú y que vino a reemplazar a la "teoría de los derechos adquiridos" 65 .

\subsection{Propiedad y concesiones estatales sobre bienes públicos}

En el caso Granier y otros (Radio Caracas Televisión) Vs. Venezuela, ya referida atrás, la Corte se pronunció sobre la presunta violación al derecho de propiedad, por el cierre del canal de televisión "Radio Caracas Televisión" (RCTV) en mayo de 2007, específicamente en relación a la decisión del Estado de reservarse la porción del espectro eléctrico que anteriormente había sido asignado a RCTV, un medio de comunicación que expresaba voces críticas contra el gobierno.

La Corte analizó, para lo que interesa ahora, si se había generado alguna vulneración a los derechos patrimoniales, relacionados con la no renovación de la concesión a RCTV para el uso del espectro electromagnético y la posible afectación al valor de la acción de propiedad de los socios de RCTV.

En relación a lo primero, la Corte constató que, de acuerdo a la Constitución venezolana, el espectro electromagnético, que hace parte de los recursos del espacio aéreo, es de plena soberanía estatal. Asimismo, de acuerdo a la legislación nacional "tal recurso es un bien del dominio público de la República, para cuyo uso y exploración deberá contarse con la respectiva concesión de conformidad con la ley"66. En base a aquello, el Tribunal concluyó "que el espectro radioeléctrico es un bien público cuyo dominio corresponde al Estado y por tanto su titularidad no puede ser reclamada por los particulares. Por ello, no es posible afirmar que RCTV y, en particular, sus accionistas hubieran adquirido algún derecho

64 SACco (2006), pp. 482.

65 La diferencia entre una y otra teoría se explica en el Boletín $N^{\circ}$ 65-2016/ Aplicación de la teoría de los hechos cumplidos: La teoría de los derechos adquiridos, recogida por la Constitución Política del Perú de 1979.

66 Ibídem, párr. 341 
o titularidad sobre el espectro"67.

Determinado esto, la Corte rechazó "el alegato de los representantes según el cual la no renovación de la concesión equivalía a una destrucción ilegitima del derecho de propiedad que tenían las presuntas víctimas sobre ella". Como ya había indicado la sentencia, no existía en el caso un derecho a la renovación o a una prórroga automática de la concesión en conformidad a la legislación local, ni tampoco está contemplada tal prerrogativa de acuerdo al derecho internacional ${ }^{68}$. En base a aquello, la Corte concluyó que la posibilidad de que el Estado renovara la concesión no podía "ser considerada como un bien o derecho adquirido ya incorporado en el patrimonio de la empresa". Era una mera expectativa $y$, "[e]n consecuencia, los beneficios económicos que los accionistas pudieren haber recibido como consecuencia de la renovación de la concesión tampoco pueden considerarse como bienes o derechos adquiridos que hicieran parte del patrimonio directo de los socios y pudieran ser protegidos por el artículo 21 de la Convención Americana en virtud de su titularidad"69.

El Tribunal señaló, asimismo, que mientras duró la concesión, la empresa había sido titular de un derecho patrimonial derivado de la concesión otorgada legalmente, y durante ese tiempo "el Estado no impidió la utilización del espectro electromagnético ni interfirió arbitrariamente en el ejercicio de los derechos derivados del contrato de concesión durante su vigencia, actos que en efecto habrían podido vulnerar el derecho a la propiedad de las presuntas víctimas"70.

Por último, las mismas razones esgrimió en relación a una alegada vulneración al derecho a la propiedad de las presuntas víctimas como consecuencia de la pérdida de valor de las acciones por la no renovación de la concesión. El Tribunal rechazó el reclamo por cuanto "la renovación de la concesión no era un derecho adquirido ya incorporado en el patri-

67 Ibídem, párr. 342

68 Ibídem, párr. 179

69 Ibídem, párr. 343

70 Ibídem, párr. 343 
monio de la empresa (...), por lo que las afectaciones económicas que por ello pudieron haber recaído sobre el valor accionario, no pueden ser exigibles como propiedad de los socios"71.

\subsection{Privación y límites de la propiedad}

El Tribunal ha sostenido, como lo ha hecho en muchas oportunidades sobre otros derechos, que el derecho de propiedad no es absoluto. Es posible, por lo tanto, poner límites a la propiedad e incluso privar a una persona de su propiedad. Veamos ahora los estándares establecidos al respecto.

La Corte recuerda que el artículo 21 de la Convención Americana reconoce el derecho a la propiedad privada y para determinar si estamos frente a una privación de bienes, la Corte no se limita "a examinar únicamente si se produjo una desposesión o una expropiación formal, sino que debe además comprobar, más allá de la apariencia, cuál fue la situación real detrás de la situación denunciada"72.

Un ejemplo paradigmático de este enfoque es la sentencia del caso de Ivcher-Bronstein Vs. Perú, del 6 de febrero de 2001. Baruch Ivcher Bronstein, la víctima en esta causa, había nacido en Israel y luego había adquirido la ciudadanía peruana. Era desde 1986 propietario mayoritario de un canal de televisión en Perú y en uno de sus programas se comenzó a transmitir informes críticos relacionados con el gobierno del entonces presidente Alberto Fujimori. A raíz de estos, en julio de 1997, se le canceló la nacionalidad peruana del Sr. Ivcher y, en conformidad con la legislación, que exigía que los propietarios de las empresas de medios de comunicación de telecomunicaciones fueran de nacionalidad peruana, en agosto de 1997 un juez peruano dispuso de las siguientes medidas:

"que se suspendiera el ejercicio de los derechos del señor Ivcher como accionista mayoritario y Presidente de la Compañía y se revocara su nombramiento como Director de la misma, se convocara judicialmente

71 lbídem, párr. 357

72 Corte IDH. Caso Ivcher Bronstein Vs. Perú. Fondo, Reparaciones y Costas. Sentencia de 6 de febrero de 2001, párr. 124. 
a una Junta General Extraordinaria de Accionistas para elegir un nuevo Directorio y se prohibiera la transferencia de las acciones de aquél. Además, otorgó la administración provisional de la Empresa a los accionistas minoritarios, hasta que se nombrase un nuevo Directorio, retirando así al señor Ivcher Bronstein del control del Canal 2"73.

Las consecuencias de la medida cautelar ordenada fueron inmediatas y evidentes, impidiéndole al Sr. Ivcher Bronstein actuar como director y presidente de la Compañía, y continuar dirigiendo la línea editorial del Canal 2. Asimismo, se le privó de la posibilidad de participar en las reuniones del consejo, donde los accionistas minoritarios pudieron tomar decisiones importantes (como la remoción de los miembros del directorio, incluido el Sr. Ivcher, y el nombramiento de nuevos miembros e incluso el aumento del capital de la Compañía). Tampoco pudo transferir sus acciones, recibir dividendos de ellas y ejercer los demás derechos que le correspondían como accionista de la Compañía.

Dado estas circunstancias, para el Tribunal, habiéndosele sustraído de esa manera de sus derechos como accionista, aun sin que existiera una expropiación formal, el Tribunal concluyó que el Sr. Ivcher había sido privado de su propiedad.

Luego, al momento de determinar si la privación antes mencionada se ajustaba con la Convención Americana, señaló que no había evidencia o argumento para confirmar que la medida cautelar ordenada por el Juez se basara en razones de utilidad pública o interés social; por el contrario, los hechos probados en este caso mostraban claramente la determinación del Estado de privar al Sr. Ivcher del control del Canal 2 al suspender sus derechos como accionista de la Compañía ${ }^{74}$. Además, no había indicios de que el Sr. Ivcher hubiese sido compensado por la privación del uso y goce de su propiedad, o que la medida que lo afectó se había adoptado de acuerdo con la ley.

Asimismo, la Corte Interamericana concluyó que los procedimientos relacionados con la restricción de los derechos del Sr. Ivcher con res-

73 Ibídem, párr. 160

74 Ibídem, párr. 129 
pecto a la Compañía, incluido el procedimiento por el cual el tribunal ordenó la medida cautelar, no cumplieron con los requisitos mínimos del debido proceso legal. A este respecto, el Tribunal observó que cuando un procedimiento se lleva a cabo en violación de la ley, las consecuencias legales correspondientes también deben considerarse ilegales. En consecuencia, la privación del uso y disfrute de los derechos del Sr. Ivcher relacionados con sus acciones en la Compañía era inadecuada y arbitraria en virtud de que no se ajustó a las disposiciones del Artículo 21 de la Convención ${ }^{75}$.

Por su parte, en relación con la posibilidad de que el Estado pueda llevar adelante formalmente expropiaciones de bienes, el Tribunal estableció los siguientes estándares en el caso de Salvador Chiriboga v. Ecuador. En ese caso, un predio de 60 hectáreas de propiedad de los hermanos Salvador Chiriboga había sido declarado de utilidad pública con fines de expropiación y de ocupación urgente, con el objetivo de construir un Parque Metropolitano en la Ciudad de Quito y destinarla a un área de protección ecológica. Los propietarios iniciaron varios procesos y recursos ante las autoridades estatales para controvertir la declaración de utilidad pública, así como para reclamar una justa indemnización de acuerdo con los términos de la legislación ecuatoriana y la Convención Americana, sin obtener ninguna resolución definitiva.

Sobre la base de estos hechos, el Tribunal estableció los siguientes estándares que buscan equilibrar el derecho de propiedad individual con los intereses sociales ${ }^{76}$. Como se analizará más adelante, ni en este caso ni en otros la Corte ha hecho una diferenciación clara entre limitación y privación del derecho de propiedad ${ }^{77}$. Los criterios fijados por el Tribunal fueron los siguientes:

a. "El derecho a la propiedad debe ser entendido dentro del contexto de una sociedad democrática donde para la prevalencia del bien común y los derechos colectivos deben existir medidas proporcionales

75 Ibídem, párr. 130

76 Excepcionalmente usaré a otras sentencias para ilustrar estos criterios.

77 LÓPEZ, (2015), p. 566. 
que garanticen los derechos individuales"78.

b. "La función social de la propiedad es un elemento fundamental para el funcionamiento de la misma, y es por ello que el Estado, a fin de garantizar otros derechos fundamentales de vital relevancia para una sociedad específica, puede limitar o restringir el derecho a la propiedad privada, respetando siempre los supuestos contenidos en la norma del artículo 21 de la Convención, y los principios generales del derecho internacional"79.

c. Para que la privación de los bienes de una persona sea compatible con la Convención debe fundarse en razones de utilidad pública o de interés social, sujetarse al pago de una justa indemnización, practicarse según los casos y las formas establecidas por la ley y efectuarse de conformidad con la Convención ${ }^{80}$.

d. En este aspecto, reiterando el criterio asentado respecto de la limitación a otros derechos consagrados en la Convención, la Corte señaló que "la restricción de los derechos consagrados en la Convención debe ser proporcional al interés de la justicia y ajustarse estrechamente al logro de ese objetivo, interfiriendo en la menor medida posible en el efectivo ejercicio de [un] derecho [...]"81.

e. En relación al principio de legalidad, ponderando la jurisprudencia de la Corte Europea de Derechos Humanos que ha señalado para estos casos que el principio de legalidad es una condición determinante para efectos de verificar la concurrencia de una vulneración al derecho a la propiedad ${ }^{22}$, la Corte Interamericana parece disponer algo distinto. En efecto, indica que "no es necesario que toda causa

78 Corte IDH. Caso Salvador Chiriboga Vs. Ecuador. Reparaciones y Costas. Sentencia de 3 de marzo de 2011, párr. 60

79 Ibídem

80 lbídem, párr. 61

81 Ibídem, párr. 62. Cita el Caso Herrera Ulloa Vs. Costa Rica. Excepciones Preliminares, Fondo, Reparaciones y Costas, Sentencia de 2 de julio de 2004, párr. 123.

82 Para el Tribunal Europeo de Derechos Humanos "[e]l respeto del principio de legalidad requiere no sólo la existencia de una ley, sino también, la calidad de la misma, lo que presupone la existencia de normas que sean suficientemente accesibles, precisas y previsibles" Rıccıo (2018), pp. 78. 
de privación o restricción al derecho a la propiedad esté señalada en la ley, sino que es preciso que esa ley y su aplicación respeten el contenido esencial del derecho a la propiedad privada", relativizando, según parece, el principio de estricta legalidad en este punto.

f. Ello no quita para la Corte que "toda limitación a éste [derecho] deba ser excepcional" de lo que "se deriva que toda medida de restricción debe ser necesaria para la consecución de un objetivo legítimo en una sociedad democrática, de conformidad con el propósito y fin de la Convención Americana", por lo que resulta siempre "necesario analizar la legitimidad de la utilidad pública y el trámite o proceso que se empleó para perseguir dicho fin" 83 .

g. Las razones de utilidad pública e interés social a que se refiere la Convención comprenden todos aquellos bienes que por el uso a que serán destinados, permitan el mejor desarrollo de una sociedad democrática ${ }^{84}$.

h. Un interés legítimo o general basado en la protección del medio ambiente como es la creación de parque público, representa una causa de utilidad pública legítima ${ }^{85}$.

i. Respecto del pago de la indemnización, ese requisito constituye un principio general del derecho internacional, el cual deriva de la necesidad de buscar un equilibrio entre el interés general y el del propietario. Dicho principio ha sido recogido en la Convención Americana en su artículo 21, al referirse al pago de una "justa indemnización". Para alcanzar el pago de una justa indemnización ésta debe ser adecuada, pronta y efectiva ${ }^{86}$. No señala que deba hacer-

83 Corte IDH. Caso Salvador Chiriboga Vs. Ecuador. Excepción Preliminar y Fondo, supra, párr. 64 y 65

84 Ibídem, párr. 73

85 Ibídem, párr. 76. Por el contrario, la Corte (en una causa relativa a incautación de libros) ha estimado que la privación de la propiedad con fundamento en un solo "interés institucional", sin mayor referencia a intereses concretos puestos en riesgo para una institución armada, es incompatible con la Convención. Corte IDH. Caso Palamara Iribarne Vs. Chile. Fondo, Reparaciones y Costas. Sentencia de 22 de noviembre de 2005, párr. 109

86 Corte IDH. Caso Salvador Chiriboga Vs. Ecuador, supra, párr. 96 
se previamente a la toma de posesión del bien.

j. Para que la indemnización sea adecuada se debe tomar como referencia el valor comercial del bien objeto de la expropiación anterior a la declaratoria de utilidad pública de éste, atendiendo el justo equilibrio entre el interés general y el interés particular utilizando los medios proporcionales a fin de vulnerar en la menor medida el derecho a la propiedad de la persona objeto de la restricción ${ }^{87}$. No indica, como se ve, que la indemnización deba ser idéntica al valor comercial del bien.

k. La determinación del avalúo de un predio objeto de expropiación por razones ambientales puede depender de varios elementos y no es siempre adecuado evaluarlo en comparación con bienes en el mercado que no presenten las mismas características. Para fijar el valor de un bien objeto de expropiación, se debe tomar en cuenta sus características esenciales, es decir, naturales (tales como su ubicación o sus características topográficas y ambientales) y jurídicas (tales como las limitaciones o posibilidades del uso del suelo y su vocación $)^{88}$.

I. De este modo, si por actos de autoridad previos a la declaración de utilidad pública, el predio objeto de la expropiación se encuentra limitado en su uso y goce, y restringidas sus posibilidades de edificación y de enajenación, el valor del terreno se encuentra afecto en relación a su potencial comercial, lo cual debe ser tomado en cuenta para efectos de la compensación debida ${ }^{89}$.

m.Aun cuando una expropiación en principio pueda justificarse en un objetivo legítimo, ella puede devenir en arbitraria cuando los recursos judiciales interpuestos en contra del acto expropiatorio exceden de un plazo razonable para su resolución, y han carecido de efectividad, privando indefinidamente a la víctima de su bien, así como

87 Ibídem, párrs. 63 y 98 .

88 Ibídem, párr. 67.

89 Ibídem, párr. 72. 
del pago de una justa indemnización, ocasionado una incertidumbre tanto jurídica como fáctica y derivando en cargas excesivas a los afectados $^{90}$

n. El Estado tiene que pagar intereses simples al propietario desde que perdió la posesión de la tierra ${ }^{91}$.

\subsection{Sobre las medidas precautorias reales y la fianza}

La adopción de medidas precautorias reales, como es la aprehensión y depósito de bienes en el marco de un proceso penal, también ha sido analizada por la Corte Interamericana de Derechos Humanos.

Estas medidas para el Tribunal no constituyen per se una violación del derecho de propiedad si se tiene en cuenta que no significa un traslado de la titularidad del derecho de dominio. Con todo, la disposición de los bienes no puede efectuarse en forma definitiva y deben restringirse exclusivamente a su administración y conservación, y a los actos de investigación y manejo de evidencia respectivos ${ }^{92}$.

La adopción de medidas cautelares reales debe justificarse previamente en la inexistencia de otro tipo de medidas menos restrictivas del derecho a la propiedad. Sólo es admisible, por lo mismo, la aprehensión y depósito de bienes frente a los cuáles se encuentran indicios claros de su vinculación con un ilícito (penal), siempre y cuando ello sea necesario para garantizar la investigación, el pago de las responsabilidades pecuniarias a que haya lugar o evitar la pérdida o deterioro de la evidencia ${ }^{93}$.

Asimismo, tanto la adopción y supervisión de estas medidas debe recaer en funcionarios judiciales, teniendo en cuenta que si desaparecen las razones que justificaron la medida precautoria, el juez debe valorar la pertinencia de continuar con la restricción, aún antes de la finalización del proceso. Si los bienes no siguen cumpliendo un papel relevante para continuar o impulsar la investigación, la medida cautelar real debe ser

90 Ibídem, párr. 117.

91 Ibídem, párr. 101.

92 Corte IDH. Caso Chaparro Álvarez y Lapo Íñiguez Vs. Ecuador, supra, párr. 187.

93 Ibídem, párr. 188 
levantada, so pena de convertirse en una pena anticipada y en una restricción manifiestamente desproporcionada del derecho a la propiedad ${ }^{94}$.

Por lo mismo, la demora en devolver la propiedad retenida, más allá de lo estrictamente necesario, constituye una violación del artículo 21 (1) de la Convención. Asimismo, cuando la propiedad es incautada, y se coloca en custodia, el Estado asume una posición de garante para su buen uso y conservación, particularmente teniendo en cuenta que las medidas de precaución no tienen un carácter sancionatorio, por lo que el deterioro de dichos bienes y la pérdida de las utilidades del mismo también constituyen privaciones al derecho de propiedad ${ }^{95}$.

Por su parte, en relación a una fianza (o su sustitución por una garantía real) como medida impuesta a un imputado por delito como medida sustitutiva de la prisión preventiva, la Corte ha desarrollado los siguientes razonamientos. En primer lugar, en relación a la proporcionalidad de la medida, tomado en cuenta la capacidad de pago del imputado, la medida no puede ser adoptada sin "contar con elementos de información objetivos para determinar de forma racional la medida cautelar que corresponde en cada caso"96. A su vez, aun cuando la medida de la fianza "no supone un cambio en la titularidad de los bienes, pues es una medida de carácter temporal", ello no impide "analizar sus efectos sobre el derecho a la propiedad contenido en el artículo 21 de la Convención"97. Ello en razón de que "la disposición de los bienes no puede efectuarse en forma definitiva ni de forma desproporcionada en relación con la situación patrimonial de la persona concernida y los riesgos procesales que se buscan prevenir"98, y es por eso que constituye una violación al derecho de propiedad "la imposición de medidas de carácter temporal que afectan el uso y goce de los bienes de una persona por períodos de tiempo tan extensos [11 y 16 meses] sin que se haga una revisión periódica de las

94 Ibídem, párr. 188.

95 Ibídem, párrs. 210 a 214.

96 Corte IDH. Caso Andrade Salmón Vs. Bolivia. Fondo, Reparaciones y Costas. Sentencia de 1 de diciembre de 2016, párr. 125.

97 Ibídem, párr. 127.

98 Ibídem, párr. 128. 
mismas"99. El mismo criterio sostuvo la Corte en relación a un proceso civil de indemnización de perjuicios en donde una medida cautelar de inhibición general para enajenar y gravar bienes se había extendido por más de quince años ${ }^{100}$.

\subsection{Poblaciones vulnerables y propiedad}

Por último, la jurisprudencia interamericana ha realizado pronunciamientos de interés en relación a población vulnerable y propiedad, específicamente a propósito de ataques y masacres dirigidas en contra de aldeas campesinas.

De acuerdo a dicha jurisprudencia, la Corte "ha estimado que se debe tener en consideración la condición socio-económica y de vulnerabilidad de las víctimas, y el hecho que los daños ocasionados a su propiedad pueden tener un efecto y magnitud mayores que los que hubiesen tenido para otras personas o grupos en otras condiciones. Los grupos de personas que viven en circunstancias adversas y con menos recursos, tales como las personas que viven en condiciones de pobreza, enfrentan un incremento en el grado de afectación a sus derechos precisamente por su situación de mayor vulnerabilidad"101. Por lo mismo, "la destrucción de hogares con condiciones básicas de pobladores, constituye, además de una gran pérdida de carácter económico, una pérdida de sus condiciones básicas de existencia, lo cual hace que la violación al derecho a la propiedad cobre especial gravedad"102.

Asimismo, en el Caso de las Masacres de Ituango Vs. Colombia la Corte señaló que la quema de las viviendas que tuvo lugar en este caso por parte de grupos paramilitares para causar el desplazamiento de la

99 Ibídem, párr. 133. En este caso las medidas cautelares impuestas estuvieron vigentes durante un período de 11 años y en otro de los casos, más de 16 años después de haber sido impuestas, sin que se hubiesen presentado "elementos de análisis que puedan justificar que esas medidas restrictivas al derecho de propiedad se extendieran por períodos tan prolongados".

100 Corte IDH. Caso Mémoli Vs. Argentina. Excepciones Preliminares, Fondo, Reparaciones y Costas. Sentencia de 22 de agosto de 2013, párr. 180

101 Corte IDH. Caso Vereda La Esperanza Vs. Colombia. Excepciones Preliminares, Fondo, Reparaciones y Costas. Sentencia de 31 de agosto de 2017, párr. 240.

102 Ibídem, párr. 241 
población civil, tuvo como efecto "la pérdida, no solo de bienes materiales, sino de todo referente social de personas que, en algunos casos, habían residido todas sus vidas en dicho poblado", es decir, "causó en los pobladores una pérdida de sus más básicas condiciones de existencia, lo cual hace que la violación al derecho a la propiedad en este caso sea de especial gravedad"103. Violación que se vincula también con el derecho a la privacidad: "la destrucción por parte de los paramilitares, con la colaboración del Ejército colombiano, de los domicilios de los habitantes de El Aro, así como de las posesiones que se encontraban en su interior, además de ser una violación del derecho al uso y disfrute de los bienes, constituye asimismo una grave, injustificada y abusiva injerencia en su vida privada y domicilio. Las presuntas víctimas que perdieron sus hogares perdieron también el lugar donde desarrollaban su vida privada"104.

Por último, en el Caso de Furlan y la familia Vs. Argentina, la Corte conoció del cumplimiento parcial de una sentencia que condenaba al Estado a pagar una indemnización de perjuicios. En el caso la víctima había terminado recibiendo apenas un tercio de lo fijado por los tribunales, debido a la aplicación de una ley que había sido creada para hacerse cargo de una grave crisis económica por la que atravesaba Argentina y que restringía en general el pago general de indemnizaciones judiciales. Para la Corte, la legislación argentina perseguía una finalidad admisible y podía entenderse como necesaria, por la difícil situación financiera existente, pero en la contracción específica que sufrió la víctima no se tuvo en cuenta que era pobre y extremadamente vulnerable. No se había adoptado en la especie ninguna previsión pecuniaria o no pecuniaria que pudiera moderar el impacto de la disminución de la indemnización dada las circunstancias específicas de la víctima, una persona que sufría de varias discapacidades que requería "del dinero ya previsto judicialmente como derecho adquirido a su favor" 105 .

103 Ibídem, párr. 182

104 Corte IDH. Caso de las Masacres de Ituango Vs. Colombia. Sentencia de 1 de julio de 2006, párr. 182.

105 Corte IDH. Caso Furlan y familiares Vs. Argentina. Excepciones Preliminares, Fondo, Reparaciones y Costas. Sentencia de 31 de agosto de 2012, párr. 222. 


\section{Análisis de la jurisprudencia interamericana sobre propiedad privada (no indígena)}

El Tribunal ha establecido una amplia concepción del derecho de propiedad que incluye todos los bienes muebles e inmuebles, elementos corporales e incorporales y cualquier otro objeto inmaterial susceptible de valor. Dentro de dicho concepto se incluyen los derechos adquiridos, la propiedad intelectual y las acciones de una empresa. Excluyendo, naturalmente, los bienes públicos.

En relación a esto, es posible sostener que la Corte si bien hace un reconocimiento amplio del derecho de propiedad, ello solo alcanza a la protección de bienes susceptibles de valor económico. Esta aclaración es importante dado el fenómeno que se ha denominado en Chile de "propietarización de los derechos", esto es la tendencia a amparar bajo el derecho de propiedad una amplia gama de posiciones jurídicas, en relación a personas o cosas, posibilidad que estaría en principio excluida de la protección del sistema interamericano. Ello sin perjuicio de entender que la propiedad pueda estar asociada a la protección de otros derechos como es el caso de la privacidad.

En relación a este punto, la crítica que subyace al análisis sobre esta "propietarización" es el peligro de desnaturalización del alcance y el contenido de los derechos humanos en sus características específicas. Si para la protección de un derecho convencional pudiere recurrirse al expediente de considerar protegible no tanto el derecho mismo como la "propiedad" que se tendría sobre él ${ }^{106}$, aquello tiene el grave inconveniente de perder de vista las particularidades propias de los derechos humanos consagrados en la Convención Americana y que permite analizar si un derecho ha sido o no violado por un Estado en su propio mérito.

En este sentido, es interesante constatar que en el Caso Lagos del Campo Vs. Perú, que es el primer caso en que la Corte condena a un Estado por la infracción al artículo 26 de la Convención Americana, o sea,

106 VergarA, (1991), p. 291. El autor en este sentido recomienda "reconducir las titularidades jurídicas, las posiciones jurídicas, los ámbitos jurídicos protegibles a lo que son, y reconocerlos, definirlos y protegerlos por lo que son, y no por medio del expediente vicioso de la propiedad". 
por "los derechos que se derivan de las normas económicas, sociales y sobre educación, ciencia y cultura, contenidas en la Carta de la Organización de los Estados Americanos", el Tribunal entendió que el despido arbitrario de un líder sindical, en virtud del cual había perdido "su empleo, la posibilidad de acceder a una pensión por jubilación, así como ejercer sus derechos como representante de los trabajadores", solo comprometió la violación al derecho a la estabilidad laboral. No amplió el análisis a una posible violación al derecho de propiedad de la víctima, aun cuando de acuerdo a la legislación que regía la empresa donde trabajaba tenía derecho a la participación en la propiedad del patrimonio empresarial, y su despido con toda probabilidad afectaba esa condición ${ }^{107}$. Ni menos acusó una violación a un supuesto "derecho de propiedad sobre la estabilidad del empleo"108.

Por otra parte, la Corte, junto con hacer un reconocimiento amplio del derecho a la propiedad, ha señalado reiteradas veces que el referido derecho no es absoluto: la ley puede subordinar dicho uso y disfrute al interés de la sociedad. Las razones de utilidad pública e interés social a que se refiere la Convención comprenden todos aquellos intereses legalmente protegidos que, por el uso asignado a los bienes, permiten un mejor desarrollo de la sociedad democrática. Ello incluye razones asociadas a la protección del medio ambiente, pero también la disposición de medidas cautelares y fianzas asociadas a la investigación de delitos o medidas cautelares en el marco de procesos civiles.

Con todo, a pesar de que la Convención Americana distingue entre la posibilidad que la ley pueda "subordinar" el uso y goce de los bienes al interés social, de la posibilidad excepcional, "en los casos y según las formas establecidas por la ley", de privar a sus bienes a una persona "mediante el pago de indemnización justa, por razones de utilidad pública o de interés social", la Corte en su jurisprudencia no ha establecido

107 Ver, Corte IDH. Caso Lagos del Campo Vs. Perú. Excepciones Preliminares, Fondo, Reparaciones y Costas. Sentencia de 31 de agosto de 2017, parrs. 141 a 153.

108 Derecho que ha sido reconocido ampliamente por los tribunales chilenos vía recurso de protección y que representa un ejemplo paradigmático de la propietarización de los derechos. NAVARRO (2012), pp. 629. 
criterios de diferenciación para uno u otro caso; ni fundado aquella en una cuestión de grado, o magnitud de la intervención, ni en relación a un elemento cualitativo de diferenciación ${ }^{109}$. Así, no ha hecho referencia a un criterio diferenciador sobre una cuestión que ha provocado amplio debate en la doctrina nacional e internacional, y que tienen una consecuencia práctica de enorme importancia: solo las privaciones de dominio estarían sujetas a ser indemnizadas; no así las restricciones al dominio, o, utilizando el lenguaje convencional, cuando el uso y goce de los bienes se "subordina" al interés social110.

Las privaciones al dominio, por otra parte, son lo que son más allá de los mecanismos formales que utilice el Estado. Como ocurrió en el Caso Ivcher Bronstein Vs. Perú, la violación al artículo 21 se configuró por la desposesión de bienes por parte del Estado mediante mecanismos que no se atuvieron a los casos y los procedimientos legales que autorizan una expropiación, y por la ausencia de una justa compensación. Y a consecuencia de aquello la Corte ordenó como medida reparatoria que el señor Ivcher "pueda realizar las gestiones necesarias para recuperar el uso y goce de sus derechos como accionista mayoritario (...)", lo que implicaba en la práctica dejar sin efecto las resoluciones judiciales que lo habían privado de sus acciones. Y, en cuanto al deber de resarcimiento sobre "los dividendos y las demás percepciones que hubieran correspondido al señor Ivcher como accionista mayoritario y funcionario de dicha Compañía", la Corte dispuso la aplicación del derecho interno, bajo el supuesto general del derecho internacional que impone reparar adecuadamente la violación de una obligación internacional que haya producido un daño ${ }^{111}$, lo cual implicaba "la plena restitución (restitutio in integrum), que consiste en el restablecimiento de la situación anterior, y la reparación de las consecuencias que la infracción produjo, así como el pago de

109 Aldunate (2006), pp. 285 a 303

110 En la doctrina chilena se ha desarrollado un amplio en base a esta distinción. Ver SiLVA (2018), pp. 21 - 27; y especialmente RAJEVIC (2018), pp. 149 a 177. Para el caso de la jurisprudencia del Tribunal Europeo de Derechos Humanos se presenta el mismo problema. LópEz (2015), p. 566; también Rıccıo, (2018), p. 124.

111 Corte IDH. Caso Ivcher Bronstein Vs. Perú. infra, párr. 177 
una indemnización como compensación por los daños ocasionados"112. Lo que, en la lógica interna local, mutatis mutandis, correspondería a declarar la invalidez de los actos que provocaron la desposesión de los bienes e indemnizar los perjuicios provocados.

La Corte a la hora de evaluar la existencia de una violación o no a la propiedad, ha centrado su análisis sobre las limitaciones o privaciones a la propiedad al cumplimiento de los principios de legalidad y proporcionalidad. Siguiendo el mismo criterio que en relación a la restricción a los derechos convencionales, ha indicado que esta debe ajustarse y fundarse en la ley, debe perseguir un objetivo legítimo en una sociedad democrática, ser necesaria y proporcional en sentido estricto.

En relación al principio de legalidad, parece ser que la Corte acepta un criterio restrictivo ${ }^{113}$ y material al respecto (al menos en un caso), poniendo la atención, más que en la incorporación explícita de causales de restricción, en que la norma o su aplicación respeten "el contenido esencial del derecho a la propiedad privada". Y en relación a aquello, lo que estaría en juego no es un examen en abstracto de una posible invasión al contenido esencial del derecho sino más bien un análisis concreto o contextualizado de ese contenido a la luz del examen de proporcionalidad.

Respecto del objetivo legítimo, es decir, si la medida o su finalidad resulta legítima (idoneidad teleológica) y si es adecuada para promover esa finalidad (idoneidad técnica) ${ }^{114}$, el Tribunal ha identificado como propósitos legítimos la protección del medio ambiente ${ }^{115}$, garantizar el resultado de una investigación judicial, el pago de responsabilidades pecuniarias o evitar la pérdida o deterioro de la evidencia en el marco de investigaciones penales ${ }^{116}$, asegurar un derecho que se encuentra en disputa en un proceso civil ${ }^{117} \mathrm{y}$, en general, un mejor desarrollo de la socie-

112 lbídem, párr. 178

113 Por criterio restrictivo se entiende que la "la ley puede delegar la regulación de los derechos fundamentales en la potestad reglamentaria de ejecución". SACco (2006), p. 493.

114 Díaz (2011), pp. 174-175

115 Corte IDH. Caso Salvador Chiriboga Vs. Ecuador, supra, párr. 76

116 Corte IDH. Caso Chaparro Álvarez y Lapo Íñiguez Vs. Ecuador, supra, párr. 188

117 Corte IDH. Caso Mémoli Vs. Argentina. Excepciones Preliminares, Fondo, Reparaciones y Costas. Sentencia de 22 de agosto de 2013, párr. 179 
dad democrática ${ }^{118}$.

En relación a la necesidad, es decir aquella parte del juicio de proporcionalidad que evalúa "si la medida sometida a control es la única idónea para favorecer la finalidad pretendida con su aplicación”, y, en el caso de haber más de una medida, si la medida elegida "es la que implica una menor afectación en los derechos fundamentales"119, el Tribunal a propósito de las medidas cautelares dispuestas en procesos seguidos en contra de las presuntas víctimas, ha sido explícito en señalar que ellas deben ajustarse estrictamente a las necesidades de la investigación o procesales y deben guardar correspondencia con el patrimonio del inculpado. Así ha dispuesto los siguientes criterios al respecto: 1) debe justificarse la inexistencia de otro tipo de medidas menos restrictivas del derecho a la propiedad $^{120}$; 2) limitarse a bienes vinculados con el ilícito cuando sea necesario para garantizar la investigación, el pago de las responsabilidades pecuniarias, o evitar la pérdida o deterioro de la evidencia ${ }^{121}$; 3) no puede prolongarse en forma indefinida ${ }^{122}$; 4) debe restringirse exclusivamente a su administración y conservación, y a los actos de investigación y manejo de evidencia respectivos ${ }^{123}$; 4) el juez debe valorar la pertinencia de continuar con la restricción en el caso que desaparezcan las razones que justificaron la medida precautoria,; además, si los bienes no siguen cumpliendo un papel relevante para continuar o impulsar la investigación, la medida cautelar real debe ser levantada ${ }^{124}$; 5) al momento de adoptar la medida se debe tomar en cuenta la capacidad de pago del imputado mediante elementos de información objetivos ${ }^{125}$; 6) tomar en cuenta los riesgos procesales que se buscan prevenir ${ }^{126}$; 7) no puede extenderse la

118 Ibídem, párr. 72

119 Diaz (2011), p. 184

120 Corte IDH. Caso Chaparro Álvarez y Lapo Íñiguez Vs. Ecuador, supra, párr. 188

121 Ibídem

122 Corte IDH. Caso Mémoli Vs. Argentina. Excepciones Preliminares, Fondo, Reparaciones y

Costas. Sentencia de 22 de agosto de 2013, párr. 180

123 Ibídem, párr. 187.

124 Ibídem, párr. 188.

125 Corte IDH. Caso Andrade Salmón Vs. Bolivia. Fondo, Reparaciones y Costas. Sentencia de

1 de diciembre de 2016, párr. 125.

126 lbídem, párr. 128. 
medida cautelar por períodos extensos sin hacer una revisión periódica de ellas ${ }^{127} ; \mathrm{y}$, por último, 8) los bienes deben ser materialmente devueltos una vez que una resolución judicial así lo ordene ${ }^{128}$.

Finalmente, en relación a la proporcionalidad en sentido estricto, es decir, la decisión sobre "cuál de los intereses constitucionales que colisionan en el caso debe preceder al otro"129, el Tribunal en el caso Furlan refiere explícitamente a esta última parte del juicio de proporcionalidad. Ahí la Corte señala que la medida estatal de rebajar sustancialmente el monto de la indemnización no satisface la proporcionalidad "porque no contempló ninguna posibilidad de aplicación que hiciera menos gravosa la disminución del monto indemnizatorio que le correspondía" a la víctima, dado que "[e]n las circunstancias específicas del caso concreto, el no pago completo de la suma dispuesta judicialmente en favor de una persona pobre en situación de vulnerabilidad exigía una justificación mucho mayor de la restricción del derecho a la propiedad y algún tipo de medida para impedir un efecto excesivamente desproporcionado, lo cual no se comprobó en este caso"130.

Es decir, si la ley de ponderación incluye los pasos de "definir el grado de la no satisfacción o de afectación de uno de los principios", como "la importancia de la satisfacción del principio que juega en sentido contrario", y finalmente, "definirse si la importancia de la satisfacción del principio contrario justifica la restricción o la no satisfacción del otro"131, para la Corte resultaba que la grave afectación a la propiedad sufrida por la víctima (de extrema pobreza y con discapacidad severa), no era compen-

127 Ibídem, párr. 133. En este caso las medidas cautelares impuestas estuvieron vigentes durante un período de 11 años y en otro de los casos, más de 16 años después de haber sido impuestas, sin que se hubiesen presentado "elementos de análisis que puedan justificar que esas medidas restrictivas al derecho de propiedad se extendieran por períodos tan prolongados".

128 Corte IDH. Caso Tibi Vs. Ecuador. Excepciones Preliminares, Fondo, Reparaciones y Costas. Sentencia de 7 de septiembre de 2004, párr. 220.

129 Díaz (2011), pp. 192. Decisión que, como se sabe, debe ser adoptada de acuerdo a la ley de ponderación: "cuanto mayor sea el grado de no satisfacción o restricción de un principio, tanto mayor tiene que ser la importancia de la satisfacción del otro". AleXY (2010), p. 105.

130 Corte IDH. Caso Furlan y familiares Vs. Argentina. Excepciones Preliminares, Fondo, Reparaciones y Costas. Sentencia de 31 de agosto de 2012, párr. 222.

131 Alexy (2010), p. 13. 
sada en el interés general de hacer frente a la grave crisis económica por la que atravesaba el país. El Estado argentino debió tomar en consideración la situación especial por la que atravesaba la víctima y no aplicar una regla indiferenciada de ahorro del gasto público en el caso ${ }^{132}$.

\section{La jurisprudencia de la Corte Interamericana: ¿republicana o liberal?}

La respuesta a esta pregunta no es simple. Probablemente podemos pensar que la jurisprudencia de Corte se debate entre dos concepciones sobre la propiedad. $Y$ creo que para graficar este punto es útil referirse a la utilización del concepto "función social de la propiedad" por parte de la Corte, y lo referido a los "derechos adquiridos"

Por un lado, como veremos enseguida, al utilizar el concepto de función social de la propiedad, el Tribunal concibe esa función como una limitación externa al derecho de propiedad, y como tal se acerca a una concepción de la misma más cercana al liberalismo. La caracteriza como "un elemento fundamental para el funcionamiento de la misma [sociedad democrática], y es por ello que el Estado, a fin de garantizar otros derechos fundamentales de vital relevancia para una sociedad específica, puede limitar o restringir el derecho a la propiedad privada, respetando siempre los supuestos contenidos en la norma del artículo 21 de la Convención, y los principios generales del derecho internacional"133. Veremos ahora os criterios que ha seguido cuando ha utilizado el concepto "función social de la propiedad".

Para resolver la tesitura entre propiedad e interés social o la utilidad pública lo ha comprendido como polos separados el uno de otro. Por eso ha señalado "que a fin de que el Estado pueda satisfacer legítimamente un interés social y encontrar un justo equilibrio con el interés del particular, debe utilizar los medios proporcionales a fin de vulnerar en la menor medida el derecho a la propiedad de la persona objeto de la restricción"

132 Corte IDH. Caso Furlan y familiares Vs. Argentina. Excepciones Preliminares, Fondo, Reparaciones y Costas. Sentencia de 31 de agosto de 2012, párr. 222.

133 Corte IDH. Caso Salvador Chiriboga Vs. Ecuador, supra, párr. 60 
(las cursivas son de nosotros) $)^{134}$. Con ello utiliza una lógica "neutra"135 muy similar a empleada por el Tribunal Europeo de Derechos Humanos que ha insistido en buscar el "justo equilibrio que debe reinar entre las exigencias del interés público y los imperativos de la salvaguarda del derecho del interesado al respecto de sus bienes"136. Por ello, para la Corte "toda limitación a éste [derecho] deba ser excepcional" de lo que "se deriva que toda medida de restricción debe ser necesaria para la consecución de un objetivo legítimo en una sociedad democrática, de conformidad con el propósito y fin de la Convención Americana", por lo que resulta siempre "necesario analizar la legitimidad de la utilidad pública y el trámite o proceso que se empleó para perseguir dicho fin"137.

Así, esta jurisprudencia ha centrado el análisis respecto de la función social de la propiedad más bien como una cuestión de conflicto de principios binarios, tendiendo a identificar el dominio como un interés estrictamente individual que externamente puede llegar a ser restringido en razón de ciertos intereses sociales. Ello enmarca en una concepción más bien liberal de la propiedad, como un derecho en principio absoluto, cuyas restricciones parecen entendidas como deberes negativos de 'no hacer' ${ }^{138}$.

A contrapelo de esta comprensión de la función social de la propiedad, cuando la Corte ha vinculado a la propiedad con valores comunitarios o relacionados con la identidad o desarrollo de la persona, y por lo mismo con un contenido y alcance particular, se inclina más a una concepción republicana de la misma. Sabemos que la propiedad, incluyendo su función social, puede entenderse como un elemento estructurante de la misma que define su contenido a partir de las características del bien sobre el que recae la titularidad, lo que trae como consecuencia el establecimiento de diversos estatutos propietarios, que incorporan en su seno la

134 Ibídem, párr. 62

135 Rıccıo (2018), pp. 190

136 BOuAZZA (2013), p. 300

137 Corte IDH. Caso Salvador Chiriboga Vs. Ecuador, supra, párr. 64 y 65

138 LÓPEZ y LÓPEZ (1998) p. 502. 
búsqueda de diferentes objetivos sociales ${ }^{139}$, dando cabida a la configuración interna de distintos tipos de propiedad ${ }^{140}$. O, que, recogiendo los alcances involucrados en la posesión de determinados bienes por ciertos sujetos, concibe la propiedad bajo un concepto que engloba un conjunto de instituciones al servicio de valores diversos, y que no puede ser reducida por lo mismo a la simple idea de una facultad de exclusión ${ }^{141}$.

Esto es lo que la doctrina ha entendido como "pluralismo propietal". La ley, en consecuencia, no se limitaría a restringir el derecho de propiedad, ella configura el contenido de la propiedad, y no de una propiedad, sino que de muchos regímenes propietarios en razón de los distintos fines que pueden satisfacer los bienes, dentro de un orden social de derecho que se quiere proyectar o preservar, y de los distintos valores que fundan la relación con las cosas, valores que a veces pueden resultar irreductibles entre sí ${ }^{142}$.

Probablemente una aproximación a esa perspectiva, aunque sin utilizar el concepto de función social de la propiedad, es la lectura que el Tribunal ha hecho cuando le ha tocado evaluar el impacto que tiene la desposesión de los bienes sobre población vulnerable, que hemos comentado aquí. Ello abre un enfoque del concepto de la propiedad que lo vincula al rol que ocupan los bienes en distintos contextos sociales y culturales en función del desarrollo e integridad de la persona concreta, del colectivo en que vive o con fines consistentes con una sociedad democrática.

De este modo, en relación a los bienes de grupos vulnerables, la Corte se alejaría de una concepción univoca de la propiedad -y que superaría, o al menos pondría en tensión, la "lógica del sujeto" que definió el orden liberal ${ }^{143}$-- abriéndose a formas particulares y divergentes de la misma,

139 FuENTES, (2018), p. 330

140 Alexander, (2013), pp. 29 - 76

141 Dagan (2011), pp. 1-29

142 Alexander, G. (2013), p. 60. También, Dagan (2011), pp. 1-29.

143 Así resume López y López la imagen del sujeto privado que es propio de la concepción liberal: "[s]ujeto de derecho único, el hombre, y formalmente igual a sí mismo en cualquier condición social, lo que conlleva, de manera implícita, dos notas esenciales: es un sujeto privado, y es un sujeto abstracto". LÓPEZ y LóPEZ, (1996), p. 413 
lo cual resulta consistente con una concepción republicana del dominio, que históricamente ha vinculado la propiedad con una función más amplia que el meramente económico o utilitario ${ }^{144}$.

Por lo mismo, es posible indicar que la Corte hace uso de dos concepciones de propiedad. Por un lado, como un derecho con pretensiones absolutas pero que debe ajustarse a las demandas externas (función social en el sentido restringido utilizado por la Corte) y, por otro lado, un derecho que se configura de un modo distinto en atención a los titulares del derecho y el lugar que ocupan determinados bienes en las vidas humanas. La diferencia de tratamiento estaría dada, como se indicó al principio de este trabajo, en atención al tipo especial de "sujeto propietario", y su particular relación con las cosas (tierras, hogares, recursos naturales, etc).

Otro aspecto a analizar sobre la interpretación desarrollada por la Corte a propósito del derecho de propiedad, es lo relativo a los llamados "derechos adquiridos". Para ello haremos una diferenciación apoyándonos en la distinción de que se ha servido de Sacco Aquino entre irretroactividad e intangibilidad. "Mientras el problema de la irretroactividad está orientado al pasado, el problema de la intangibilidad está orientado exclusivamente hacia el futuro. La irretroactividad dice relación con la prohibición de "trasladar" una norma hacia el pasado, extendiendo sus efectos a hechos anteriores a su vigencia. La intangibilidad, por su parte, se refiere a la inmutabilidad de las situaciones o los actos jurídicos creados bajo el imperio de una norma, los que a pesar de eventuales cambios en la normativa quedan regidos por las prescripciones de la norma antigua"145.

Para la Corte, la aplicación de una ley posterior a un derecho ya adqui-

144 Para Waldron "[l]a forma más común de argumentación justificativa (sobre la propiedad) es consecuencialista: la gente en general está mejor cuando una determinada clase de recursos está gobernada por un régimen de propiedad privada que por un sistema alternativo. Bajo la propiedad privada, se dice, los recursos se utilizarán más sabiamente o se utilizarán para satisfacer un conjunto de necesidades más amplio (y quizás más variado) que bajo cualquier otro sistema alternativo, de modo que se incrementará el disfrute general que los humanos obtienen de un stock dado de recursos" (traducción libre). WALDRON, (2004). De ahí que Bullard afirma que "la desaparición de la propiedad sería no solo innatural sino además disfuncional. Reduciría el éxito de nuestra especie y pondría en riesgo los niveles de bienestar que hemos alcanzado a nivel global". BULLARD (2018), p. 74

145 SACCO (2006), p. 483. 
rido privando o restringiendo el uso o goce de bienes ya incorporados al patrimonio de una persona de acuerdo a la legislación vigente, constituye en principio una infracción al artículo 21 de la Convención Americana, a menos que se realice fundada en los motivos que autoriza el instrumento internacional, y bajo las formas y presupuestos que ella prescribe (irretraoctividad). Pero no parece claro que la Corte, al menos al tenor de sus pronunciamientos, incorpore dentro de los derechos adquiridos la inmutabilidad de los beneficios que pueda contemplar una determinada ley, como puede ser el caso de una precisa escala de pensiones (intangibilidad).

Porque una cosa distinta es evaluar la intervención a la propiedad sobre bienes ingresados al patrimonio de una persona en virtud de una ley vigente, que pretender que en virtud de la "teoría de los derechos adquiridos" no se pueden alterar a futuro los efectos de dicha legislación a quienes son sus beneficiarios, pretendiendo una suerte de inmutabilidad en las condiciones dispuestas por la ley, del tal modo que la protección pudiera alcanzar a los cambios en el orden jurídico que tengan efectos patrimoniales. El Tribunal no ha consagrado nada equivalente a una suerte de derecho subjetivo a las situaciones creadas por ley ${ }^{146}$. Lo cual es una opción consistente con la filosofía republicana, como lo hemos visto atrás, donde es el legislador quien regula el alcance y contenido de la propiedad sobre las cosas. Cercana a la concepción propietaria liberal, por el contrario, es entender que los derechos patrimoniales o situaciones con efectos patrimoniales pertenecen a un campo intangible (cuya disposición está ajena a la configuración legal), en una suerte de proyección de la concepción de un derecho pre-estatal de propiedad ${ }^{147}$.

Para graficar este punto, parece interesante contrastar lo dicho por la Corte con lo resuelto por la Comisión Interamericana de Derechos Humanos en el Informe $N^{\circ} 38 / 09$, que fue expedido (otra vez) en relación con las modificaciones legales que tuvieron lugar en Perú respecto de

146 Aldunate; Olmos (1997) pp. 203 y 204.

147 Esta idea me fue sugerida por el profesor Jorge Ulloa Plaza. 
pensiones "renovables"148. Ahí la Comisión, invocando sobretodo jurisprudencia del Tribunal Europeo de Derechos Humanos, entendió que la protección de la propiedad alcanzaba a priori la intangibilidad de las pensiones y las condiciones de cálculo establecidas en la ley, y evaluó una posible afectación al derecho a la propiedad privada como consecuencia la disminución de los montos de las futuras prestaciones sociales por el cambio legislativo. Ello bajo el entendido que "los efectos patrimoniales de un régimen pensional al cual se han efectuado contribuciones o cuyos requisitos legales se encuentran cumplidos, deben entenderse dentro del alcance del derecho a la propiedad consagrado en el artículo 21 de la Convención Americana"149.

Pero este no parece ser el criterio seguido por la Corte. En el Caso Abrill Alosilla, que ya vimos, no fue aquello lo que la Corte entendió como un derecho adquirido ${ }^{150}$. De hecho, limitó su análisis sólo a lo relativo a aquellas sumas devengadas mientras la legislación permanecía vigente, porque el sistema local los reconocía como adquiridos, pero no se pronunció sobre si esos derechos pueden extenderse en el tiempo como un

$148 \mathrm{CIDH}$ (2009), Informe $N^{\circ}$ 38/09, Caso 12.670. Admisibilidad y Fondo Asociación Nacional de ex Servidores del Instituto Peruano de Seguridad Social y otras, Perú, 27 de marzo de 2009.

149 Ibídem, párr. 103. No obstante que planteó que dicha afectación a la propiedad, en el caso particular, era permisible por cuanto se satisficieron en la especie los principios de legalidad, proporcionalidad y no se transgredió la prohibición de regresividad al tratarse de un derecho económico y social). Ibídem, párrs. 113-146. Por su parte, el comisionado Paolo Carozza en el Informe que analizamos sostuvo sobe el punto una posición distinta. Calificó como "totalmente superfluo" la aplicación del test de legalidad y proporcionalidad al caso, por cuanto el Estado puede discrecionalmente mantener o eliminar los "derechos propiedad que hayan sido creados conforme a la legislación interna". Para el comisionado el artículo 21 no contendría "ningún requisito de 'progresividad' ni 'derechos adquiridos' mediante los cuales no puedan ser derogados los derechos de propiedad que hayan sido creados conforme a la legislación interna". Así, la Convención protegería a los poseedores de estos derechos legales de la interferencia irrazonable o discriminatoria, "sólo en la medida en que se cumpla la condición preliminar de que la legislación interna cree o mantenga la existencia del derecho". Fuera de esa hipótesis nada podía ser controlado por los órganos de supervisión americanos; no existiría propiamente una protección convencional a la subsistencia de una propiedad creada por ley. Ibídem, pp. 5 y 6 (Voto concurrente del comisionado Paolo Carozza).

150 En Chile existe una tradición que entiende que los beneficios otorgados por ley a funcionarios públicos se integran como derechos adquiridos a sus beneficiarios y por lo mismo el Estado no está habilitado para suprimirlos. LetelieR (2010), pp. 215-224. Doctrina que ha encontrado recepción en la jurisprudencia pero que también ha encontrado detractores. FIGUEROA (2016), pp. 167-186. 
bien incorporado al patrimonio de los beneficiarios, como a juicio de la Comisión sí lo ha hecho la Corte Europea. Explícitamente la Corte Interamericana indicó que no se estaba decidiendo respecto a la aplicación del sistema de "ratios salariales", sino exclusivamente en relación a "los montos que ya habían ingresado al patrimonio de los trabajadores, así como a los incrementos al salario que se hubieran establecido bajo el sistema de ratios hasta antes de su derogación"151.

\section{Bibliografía}

AldunAte, Eduardo (2008): Derechos Fundamentales (Santiago, Legal Publishing).

AldunAte, Eduardo; Fuentes, Jessica (1997): "El concepto del derecho de propiedad en la jurisprudencia constitucional chilena y la teoría de las garantías de instituto" en Revista de Derecho de la Pontificia Universidad Católica de Valparaíso ( $\left.\mathrm{N}^{\circ} 18\right)$, pp. 195-221, [fecha de consulta: 23 de diciembre de 2018]. [Disponible en: http://www.rdpucv.cl/index. php/rderecho/article/viewArticle/366].

AleXANDER, Gregory (2013): “Aproximaciones teóricas contemporáneas a la función social de la propiedad: Pluralismo y propiedad”, en Bonilla, Daniel La función social de la propiedad (coord.), pp. 29 a 71. (Buenos Aires: Eudeba, Universidad de Buenos Aires).

AleXY, Robert (2002): Teoría de los derechos fundamentales. (Madrid, Centro de Estudios Constitucionales).

—. (2010): "Derecho fundamentales, ponderación y racionalidad" en El canon neoconstitucional, pp. 97-109. (Bogotá, Universidad Externado de Colombia).

- (2008): "La fórmula del peso", en El principio de proporcionalidad en la interpretación jurídica, pp. 13-42 (Quito, Ministerio de Justicia y Derechos Humanos).

BouAzZ; Omar (2013): "Notas de Jurisprudencia del Tribunal Europeo de Derechos Humanos" en Revista de Administración

151 Corte IDH. Caso Abrill Alosilla y otros Vs. Perú. Fondo, Reparaciones y Costas. Sentencia de 4 de marzo de 2011, párr. 84. 
Pública (enero-abril) pp. 287-306 [fecha de consulta: 3 de diciembre de 2018]. [Disponible en: [fecha de consulta: 1 de diciembre de 2018]. [Disponible en: https://scielo.conicyt.cl/scielo. php?script=sci_arttext\&pid=S0716-54552008000100013].

BullaRD, Alfredo (2018): "Y si eliminamos la propiedad?, pp. 59-75 (Madrid, Marcial Pons).

Cordero, Eduardo; Aldunate, Eduardo (2008): "Evolución histórica del concepto de propiedad", en Revista de Estudios Histórico-Jurídicos XXX, pp. 345 - 385 [fecha de consulta: 1 de diciembre de 2018]. [Disponible en: https://scielo.conicyt.cl/scielo. php?script=sci_arttext\&pid=S0716-54552008000100013].

CORDERO, Eduardo (2008): "De la propiedad a las propiedades: La evolución de la concepción liberal de la propiedad" en Revista de Derecho de la Pontificia Universidad Católica de Valparaíso ( $N^{\circ} 31$ ), pp. 493-525 [fecha de consulta: 30 de octubre de 2018]. [Disponible en: https:// scielo.conicyt.cl/pdf/rdpucv/n31/a14.pdf].

CRIsti, Renato; Ruiz TAgle, Pablo (2014): Propiedad, Bien Común y Poder Constituyente. (Santiago, LOM Ediciones).

Dagan, Hanoch (2011): "Pluralism and Perfectionism in Private Law", en Columbia Law Review (Vol. 112, No. 6), pp. 1409-1446 [fecha de consulta: 5 de noviembre de 2018]. [Disponible en: https://ssrn.com/ abstract $=1868198]$.

DíAz, Iván (2011): "La aplicación del principio de proporcionalidad en orden a juzgar sobre la licitud o ilicitud de una restricción a derechos fundamentales", en Revista de Derecho de la Pontificia Universidad Católica de Valparaíso ( $N^{\circ} 36$ ), pp.167-206. [fecha de consulta: 20 de septiembre de 2018]. [Disponible en: https://scielo.conicyt.cl/scielo. php?script=sci_abstract\&pid=S0718-68512011000100005\&lng=es\&n$\mathrm{rm}=\mathrm{iso}]$.

Domínguez, Ramón (1996): "Aspectos de la constitucionalización del derecho civil chileno", en Revista de Derecho y Jurisprudencia y Gaceta de los Tribunales ( $\left.\mathrm{N}^{\circ} 3-1996\right)$, pp. 107-137 [fecha de consulta: 5 de septiembre de 2018]. [Disponible en: https://app.vlex.com/\#sources/5016/ issues/219473]. 
Duguit, León (s.f.) Las transformaciones del Derecho privado desde el Código de Napoleón (Madrid, Francisco Beltran).

Fermandois, Arturo (2010): Derecho Constitucional Económico (Santiago, Ediciones UC).

FigueroA, Gonzalo (2016): Curso de Derecho Civil I, (Santiago, Editorial Jurídica de Chile)

FUENTES, Jessica (2018): El derecho de propiedad (Santiago, DER Ediciones Limitada)

FuenzalidA, Sergio (2014): "Propiedad, propiedades y propiedad indígena" en Revista Chilena de Derecho y Ciencia Política, pp. 95-117.

Grossı, Paolo (1992): La propiedad y las propiedades. Un análisis histórico. (Madrid: S.L. Civitas Ediciones).

Kelsen, Hans (2003): Teoría pura del Derecho. (Buenos Aires, Eudeba, Universidad de Buenos Aires).

LeTELIER, Valentín (2010): "La irretroactividad de las leyes en el derecho público", en Doctrinas esenciales Derecho Constitucional, pp. 215-224 (Santiago, Editorial Jurídica de Chile).

LoCKE, John (2003): Segundo ensayo sobre el gobierno civil (Buenos Aires, Losada).

LÓPEZ y LóPEZ, Ángel (1998): "El derecho de propiedad. Una relectio" en Revista Anuario de Derecho Civil (Vol. 51, No 4) pp. 1637-1692 [fecha de consulta: 21 de septiembre de 2018]. [Disponible en: https://dialnet. unirioja.es/servlet/articulo?codigo=46941].

—. (1996) "Estado social y sujeto privado: una reflexión finesecular" en Quaderni fiorentini per la storia del pensiero giuridico moderno (XXV), pp. 409-466 [fecha de consulta: 20 de septiembre de 2018]. [Disponible en: https://dialnet.unirioja.es/servlet/articulo?codigo=5217955].

LóPEZ, Sebastián (2015): "La propiedad y su privación o restricción en la jurisprudencia de la Corte Interamericana" en lus et Praxis, pp. 531 - 576 [fecha de consulta: 20 de septiembre de 2018] [Disponible en: en: <https://scielo.conicyt.cl/scielo.php?script=sci_arttext\&pi$\mathrm{d}=$ S0718-00122015000100015\&Ing=es\&nrm=iso>. ISSN 0718-0012. http://dx.doi.org/10.4067/S0718-00122015000100015].

NAVARRo, Enrique (2012): “35 Años del recurso de protección notas sobre 
su alcance y regulación normativa" en Estudios Constitucionales (año $10, N^{\circ}$ 2) 617 - 642 [fecha de consulta: 10 de agosto de 2018] [Disponible en: https://scielo.conicyt.cl/pdf/estconst/v10n2/art17.pdf].

MARTí, José Luis (2014): "Propiedad Republicana y bienes comunes" en la concepción republicana de la propiedad, pp. 167-268 (Madrid, Fundación Coloquios Jurídico Europeo).

MacPherson, C.B (2005): La teoría política del individualismo posesivo (Madrid, Editorial Trotta).

Penallillo, Daniel (2010): Los Bienes. La Propiedad y Otros Derechos Reales (Santiago, Editorial Jurídica de Chile).

PeÑA, Carlos (2018): "Kant: de la propiedad al contrato social", en Filosofía del Derecho Privado, pp. 45-58 (Madrid, Marcial Pons)

Philip Pettit Republicanismo: una teoria sobre la libertad y el gobierno (Barcelona, Paidos).

Pocock, J.G.A (2016): El momento maquiavélico. El pensamiento político florentino y la tradición republicana atlántica. (Madrid, Editorial Tecnos) RAJEVIC, Enrique (2018): "Nulidad o responsabilidad. El desfiladero de las limitaciones del derecho de propiedad", en Derecho de Propiedad Enfoques de Derecho Público, pp. 149 a 177 (Santiago, DER Ediciones Limitada).

Rıccıo, Ángelo (2018): La propiedad en el marco del convenio europeo de derechos humanos (Madrid, Editorial REUS).

Rose, Carol (1985): "Possession as the Origin of Property" en Yale Law School Legal Scholarship Repository Faculty Scholarship [fecha de consulta: 5 de agosto de 2018] [Disponible en: http://digitalcommons. law.yale.edu/fss_papers/1830]

—. (2001): "La propiedad como narración: Perspectivas desde la teoría de los juegos, la teoría narrativa y la teoría feminista" en Derecho y Humanidades. [fecha de consulta: 5 de septiembre de 2018] [Disponible en: https://revistas.uchile.cl/index.php/RDH/article/view/25752]

Rosseau, Jean- Jaques (2001): Discurso sobre la Economía política (Madrid, Editoria Tecnos)

-. (2003): Del contrato social. Discurso sobre las ciencias y las artes. Discurso sobre el origen y los fundamentos de la desigualdad entre los 
hombres (Madrid, Alianza Editorial).

Ruiz-Tagle, Pablo (2014a): La concepción republicana del derecho de propiedad. (Madrid, Fundación Coloquios Jurídico Europeo).

—. (2014b): "La propiedad en el constitucionalismo republicano y su aplicación al Chile actual" en El constitucionalismo del miedo, pp. 31-72 (Santiago, LOM Ediciones).

SAcco, Sabina (2006): "La Constitución de 1980 como Fundamento y Origen de una Teoría Constitucional de la Irretroactividad" en Revista chilena de Derecho (vol.33).3, pp. pp. 479 - 508 [fecha de consulta: 12 de diciembre de 2018] [Disponible en: https://scielo.conicyt.cl/pdf/rchilder/ v33n3/art03.pdf].

SiLVA, María Pía (2018): "El estatuto del derecho de propiedad en la Constitución de 1980", en Derecho de Propiedad Enfoques de Derecho Público, pp. 5-30 (Santiago, DER Ediciones Limitada).

Vergara, Alejandro (1991): "La propietarización de los derechos" en Revista de Derecho de la Pontificia Universidad Católica de Valparaíso ( $\left.N^{\circ} 14\right)$, pp. 281 a 291 [fecha de consulta: 15 de enero de 2019] [Disponible en: http://www.rderecho.equipu.cl/index.php/rderecho/article/ view/255/235].

VILLEY, Michel (1984): "Notas sobre el concepto de propiedad" en Revista de Derecho Público ( $N^{\circ} 35$ ), pp. 67-81 [fecha de consulta: 3 de enero de 2019] [Disponible en: https://revistaderechopublico.uchile.cl/index. php/RDPU/article/view/43718/45737].

WALDROM, Jeremy (1988): The right to private property. (Berkeley University of California).

- (2004): "Property and Ownership", en Standford Encyclopedia of Philosophy [fecha de consulta: 3 de noviembre de 2019] [Disponible en: https://plato.stanford.edu/entries/property/].

Sentencias Corte Interamericana de Derechos Humanos

Caso Ivcher Bronstein Vs. Perú (2001). Fondo, Reparaciones y Costas. Sentencia de 6 de febrero de 2001

Caso "Cinco Pensionistas" Vs. Perú. Fondo, Reparaciones y Costas. 
Sentencia de 28 de febrero de 2003

Corte IDH. Caso Herrera Ulloa Vs. Costa Rica. Excepciones Preliminares, Fondo, Reparaciones y Costas. Sentencia de 2 de julio de 2004 Corte IDH. Caso Palamara Iribarne Vs. Chile. Fondo, Reparaciones y Costas. Sentencia de 22 de noviembre de 2005

Caso de las Masacres de Ituango Vs. Colombia. Sentencia de 1 de julio de 2006

Caso Chaparro Álvarez y Lapo Íñiguez Vs. Ecuador. Excepciones Preliminares, Fondo, Reparaciones y Costas. Sentencia de 21 de noviembre de 2007

Caso Perozo y otros Vs. Venezuela. Excepciones Preliminares, Fondo, Reparaciones y Costas. Sentencia de 28 de enero de 2009

Caso Salvador Chiriboga Vs. Ecuador. Reparaciones y Costas. Sentencia de 3 de marzo de 2011

Caso Abrill Alosilla y otros Vs. Perú. Fondo, Reparaciones y Costas. Sentencia de 4 de marzo de 2011

Caso Mémoli Vs. Argentina. Excepciones Preliminares, Fondo, Reparaciones y Costas. Sentencia de 22 de agosto de 2013

Caso Granier y otros (Radio Caracas Televisión) Vs. Venezuela. Excepciones Preliminares, Fondo, Reparaciones y Costas. Sentencia de 22 de junio de 2015

Caso Andrade Salmón Vs. Bolivia. Fondo, Reparaciones y Costas. Sentencia de 1 de diciembre de 2016

Caso Vereda La Esperanza Vs. Colombia. Excepciones Preliminares, Fondo, Reparaciones y Costas. Sentencia de 31 de agosto de 2017 Caso Furlan y familiares Vs. Argentina. Excepciones Preliminares, Fondo, Reparaciones y Costas. Sentencia de 31 de agosto de 2012 Caso Lagos del Campo Vs. Perú. Excepciones Preliminares, Fondo, Reparaciones y Costas. Sentencia de 31 de agosto de 2017

INFORMES Y OTROS

Comisión Interamericana de Derechos Humanos (2009), Informe $N^{\circ}$ 38/09, Caso 12.670. Admisibilidad y Fondo Asociación Nacional de ex 
Servidores del Instituto Peruano de Seguridad Social y otras, Perú, 27 de marzo de 2009

Organización de Estados Americanos EA (1969) Conferencia Especializada Interamericana Sobre Derechos Humanos, San José, Costa Rica, 7-22 de noviembre de 1969, Actas y Documentos, Secretaria General, Organización De Los Estados Americanos, Washington, D.C. Poder Judicial Perú (2016) Aplicación de la teoría de los hechos cumplidos: La teoría de los derechos adquiridos, recogida por la Constitución Política del Perú de 1979

Corte Interamericana de Derechos Humanos, Pueblos Indígenas y Tribales, Cuadernillo de Jurisprudencia de la Corte Interamericana de Derechos Humanos $N^{\circ} 11$.

Corte Interamericana de Derechos Humanos. Opinión Consultiva OC$22 / 16$ de 26 de febrero de 2016. Titularidad de derechos de las personas jurídicas en el Sistema Interamericano de Derechos Humanos (Interpretación y alcance del artículo 1.2, en relación con los artículos 1.1, 8, 11.2, 13, 16, 21, 24, 25, 29, 30, 44, 46, y 62.3 de la Convención Americana sobre Derechos Humanos, así como del artículo $8.1 \mathrm{~A}$ y B del Protocolo de San Salvador). 